Portland State University

PDXScholar

Spring 5-28-2015

\title{
The Erosion of Coastal Sediment and Regeneration of Rhizophora mangle Following Anthropogenic Disturbance on Turneffe Atoll, Belize
}

Heather Lyn Hayden

Portland State University

Follow this and additional works at: https://pdxscholar.library.pdx.edu/open_access_etds

Part of the Environmental Sciences Commons, and the Forest Sciences Commons Let us know how access to this document benefits you.

\section{Recommended Citation}

Hayden, Heather Lyn, "The Erosion of Coastal Sediment and Regeneration of Rhizophora mangle Following Anthropogenic Disturbance on Turneffe Atoll, Belize" (2015). Dissertations and Theses. Paper 2365.

https://doi.org/10.15760/etd.2363

This Thesis is brought to you for free and open access. It has been accepted for inclusion in Dissertations and Theses by an authorized administrator of PDXScholar. Please contact us if we can make this document more accessible: pdxscholar@pdx.edu. 
The Erosion of Coastal Sediment and Regeneration of Rhizophora mangle Following Anthropogenic Disturbance on Turneffe Atoll, Belize

by

Heather L. Hayden

A thesis submitted in partial fulfillment of the requirements for the degree of

\author{
Master of Science \\ in \\ Environmental Science and Managment
}

Thesis Committee:

Elise E. Granek, Chair

J. Alan Yeakley

Jeff J. Gerwing

Portland State University

2015 
(C) 2015 Heather L. Hayden 


\begin{abstract}
As communities and managers become aware of the long-term impacts of mangrove loss, estimated at 1-2\% per year, interest in sediment erosion and mangrove rehabilitation has increased substantially. In this thesis project I 1) examine erosion rates within coastal fringing Rhizophora mangle ecosystems following mangrove clearing and compare these rates to accretion rates in intact mangroves; and 2) investigate the abiotic factors influencing mangrove seedling survival and regeneration of naturally colonizing $R$. mangle, in historic mangrove habitat after anthropogenic clearing.

Differences in erosion were compared between patches of open-coast intact and anthropogenically cleared $R$. mangle to quantify the sediment trapping function provided by mangroves and its loss following clearing over a 24 month period. Growth rates of mangrove seedlings in intact forest were compared to seedlings in cleared areas. Seedling growth indicators were measured on 100 seedlings at five sites (50 in the intact and 50 in the cleared areas). To examine the limiting factors on seedling growth rates, nutrient addition and wave protection treatments were applied to seedlings in three disturbed areas.
\end{abstract}

Sites within intact mangroves had sediment accretion $(\mathrm{M}=+3.83 \mathrm{~mm})$ while areas cleared of mangroves had sediment erosion $(M=-7.30 \mathrm{~mm})$. Seedling growth (height) over the 2 year study period significantly differed between intact mangrove $(M=15.6$ $\mathrm{cm})$ and cleared $(\mathrm{M}=10.24 \mathrm{~cm})$ areas. Seedling mortality from the cleared areas $(31 \%)$ differed from the intact areas (13\%). Average seedling growth (height) was: greater with both nutrient/wave $(\mathrm{M}=18.4 \mathrm{~cm})$ and nutrient $(\mathrm{M}=17.65 \mathrm{~cm})$ treatments compared to 
controls $(\mathrm{M}=10.8 \mathrm{~cm})$, which suggests that providing nutrients and/or wave protection result in growth outputs comparable to seedlings found in intact mangroves.

This study may prove to be useful in identifying areas that are most vulnerable to erosion following mangrove removal and ideal location of restoration following mangrove removal. Areas cleared of mangroves can lead to intensified erosion in areas where fringing reefs are not continuous. When managers are determining areas to focus resources for restoration, focusing on areas with nutrient rich habitat may result in higher survival rates and growth outputs. 


\section{ACKNOWLEDGEMENTS}

This project was funded in part by Granek Lab Funds from Portland State University. In addition, in-kind support was provided by Oceanic Society the 2008 Belize Capstone.

I would like to thank the following people for their generous help with this project:

My thesis committee for support and flexibility in completing this project. I am particularly grateful to to my advisor, Elise Granek, for her support and encouragement throughout this process.

The Portland State University 2008 Belize Capstone Class: Becca Aaby, Sam Higgens, Marissa Lee, Tamara Linde, Hilary Moore, and Derek. I would not have been able to set up this research without your dedication and ability to fend off mosquitos. I can never repay your generosity and dedication.

My field assistants: Amanda Hillman, Danielle Nelson, and Catalina Ross. Thank you for the endless hours of note taking while I measured 626 seedlings. Amazing patience.

Calabash Caye Field Station and Oceanic Society, for their logistical support during my visits to the Atoll.

Marion Usher, for inviting me and my field assistants into your home and providing logistical ease upon my arrival and departures.

Billy, my boat tender, without Billy this research would not have been possible. Sharing his time and home with me was a gift.

To all my friends that have heard on numerous occasions me start a sentence with: "I will be working on my thesis..." over the years. Thank you for being my cheering squad.

To my family, David Hayden and Rachel Talbot, thank you for all your support and encouragement from across the pond.

To Pearl Waldorf, thank you for believing in me. 


\section{TABLE OF CONTENTS}

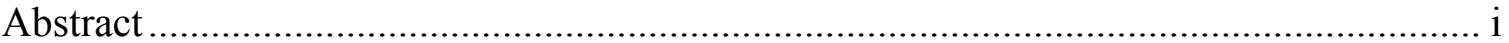

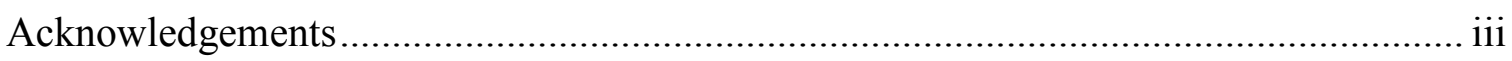

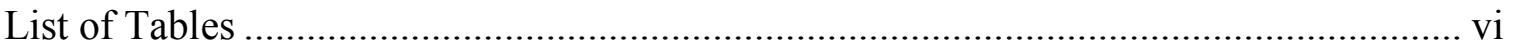

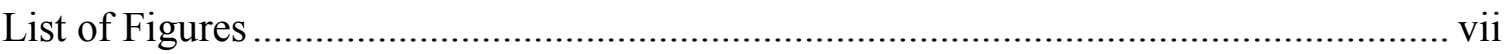

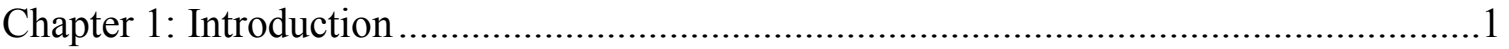

Chapter 2: Erosion of Coastal Sediment Resulting From Anthropogenic Mangrove Clearing .................................................................... 4

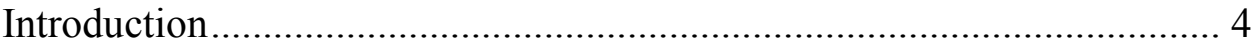

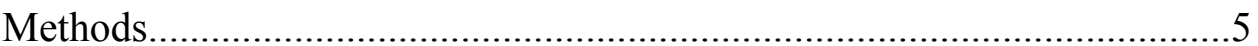

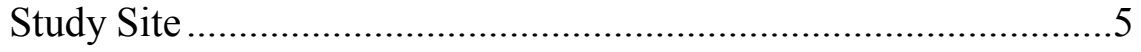

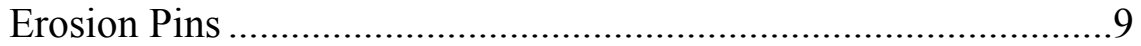

Data Analysis ................................................................. 10

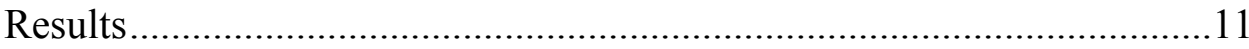

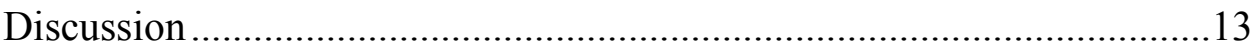

Chapter 3: Nutrients Enhance Rhizophora Mangle Seedling Regeneration, Turneffe Atoll, Belize ...........................................................................17

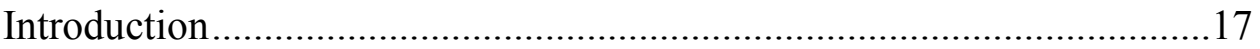

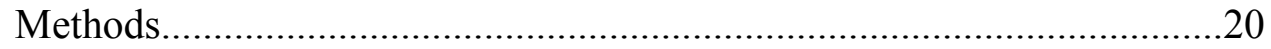

Study Site ..................................................................... 20

Anthropogenic Disturbance Events During Study......................25

Field Observations and Sampling ............................................. 25

Intact vs Cleared: Mortality and Growth Parameters.........25

Seedling Growth Experiment ........................................ 26 


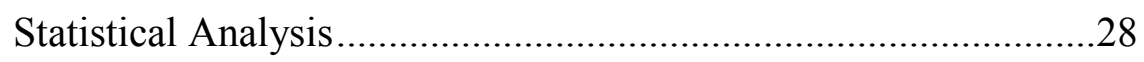

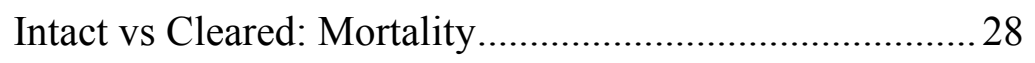

Intact vs Cleared: Growth Parameters .................................28

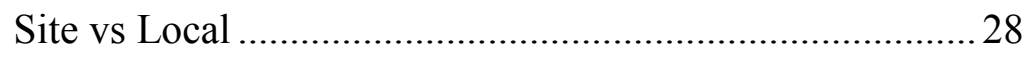

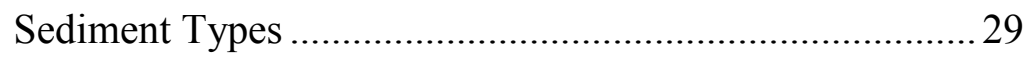

Treatments: Seedling Growth Experiment ..........................29

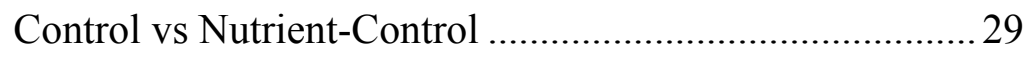

Treatments vs Sediment ……………………………......... 30

Nutrient/Wave and Nutrient vs Intact Mangrove ................ 30

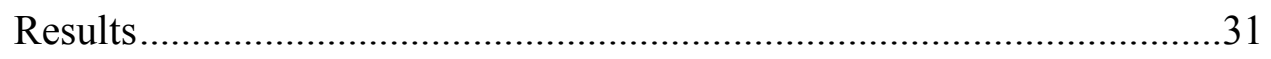

Intact vs Cleared: Mortality .............................................................

Intact vs Cleared: Growth Parameters ..............................................32

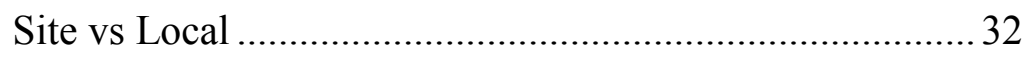

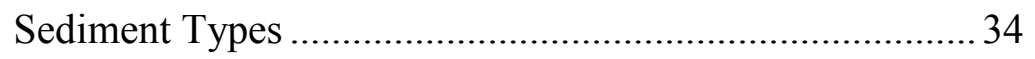

Treatments: Seedling Growth Experiment.......................................36

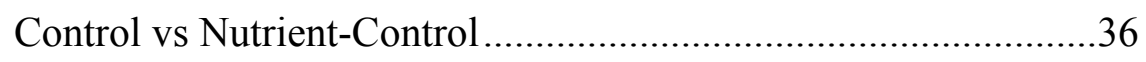

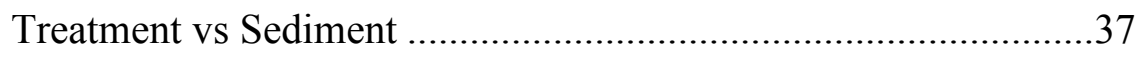

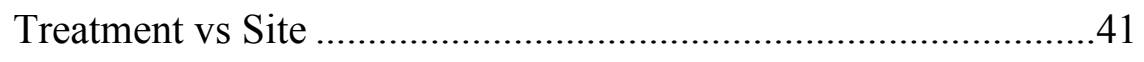

Nutrient/Wave and Nutrient vs Intact Mangrove............................45

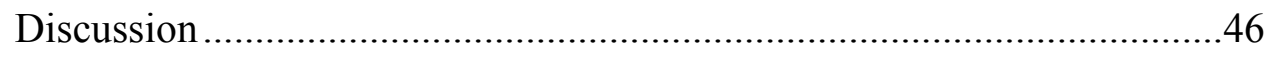

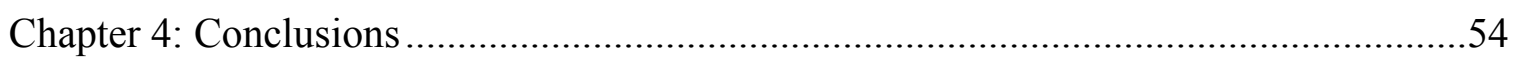

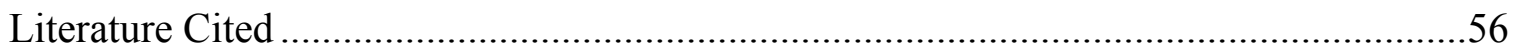




\section{LIST OF TABLES}

Benefits and threats to mangrove ecosystems ..........................................

2.1 Fringe reef structure, anthropogenic disturbances during study period, and mean accretion and erosion rates at cleared and intact plots for each site 12

Site description and locations of treatment application ................................23

Experimental design for treatment application .......................................26

3.3 Summary of Tukey HDS results for growth (height) according to site

3.4 Difference in growth parameters between intact and cleared

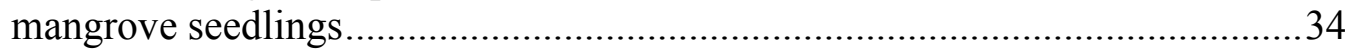

3.5 Difference in growth parameters of cleared area seedlings by sediment type and results for analysis

3.6 Difference in growth parameters ANOVA result of cleared area seedlings by sediment type and treatments.

3.7 Difference in growth parameters Tukey HDS test results of cleared area seedlings by sediment type and treatments

3.8 Differences in growth parameters Quasi Poisson GLM results and means of cleared area seedlings by sediment type and treatments over two year study

3.9 ANOVA growth results for treatment* site

3.10 Tukey HSD test growth (height) analysis for treatments*site pairs vs sites

3.11 Tukey HSD test diameter analysis of treatment* site pairs vs sites 45

3.12 Height growth ANOVA results of cleared and nutrient/wave and nutrient compared to intact mangroves 


\section{LIST OF FIGURES}

2.1 Location of study area with sites marked on Turneffe Atoll map. ...................7

2.2 Seedling density at Fisherman's Cut intact and cleared. .............................

2.3 Accretion/erosion rates of sediment between June 2008 and June 2010 at five study sites on Turneffe Atoll. ................................................. 13

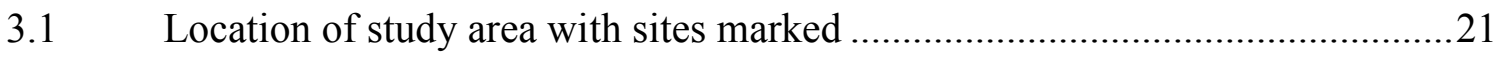

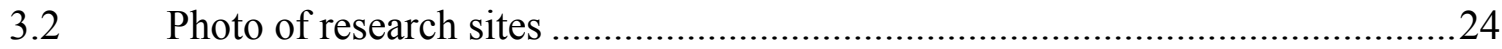

3.3 Photo of dredging at Airport and Ropewalk 2009 .......................................25

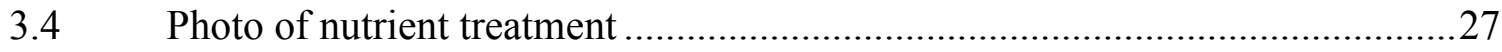

3.5 Figure showing percent mortality by sites, Airport and Ropewalk experienced anthropological disturbances after 2 years ................................. 31

3.6 Differences in growth rates (a) height $(\mathrm{mm})$, (b) diameter $(\mathrm{mm})$, (c) leaves, (d) nodes, (e) prop roots, and (f) branches between intact (blue) and cleared (red) mangroves over two years ..............................33

3.7 Differences in growth parameters by sediment in cleared areas......................36

3.8 Differences in growth responses to treatment in cleared areas by

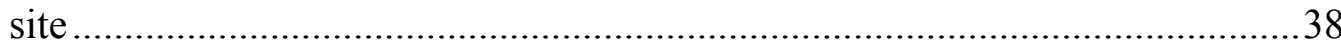

3.9 Photo of a control seedling and nutrient/wave seedlings ............................42

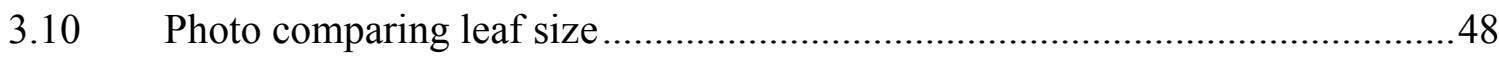

3.11 Photo comparing leaf size, control and nutrient from Calabash .....................49 


\section{CHAPTER 1: INTRODUCTION}

Coastal mangrove forests along tropical shorelines serve as an important interface between land and sea. In the last decade, mangrove ecosystems have been recognized for their key role in ecological functioning of adjacent nearshore habitats and provide a number of ecosystem services to surrounding communities (Mumby et al. 2004).

Mangroves have extraordinarily high rates of productivity, which support both terrestrial and marine food webs and contribute significant nutrients to offshore fisheries (Boullion et al. 2008). Mangroves also provide important nursery habitat for juvenile invertebrates and fish (Mumby et al. 2004).

Mangroves serve as sediment "traps" catching terrestrial sedimentation and preventing it from smothering subtidal coral reefs, thereby filtering terrestrial runoff before it reaches coastal marine ecosystems (Bird 1971, Wolanski and Ridd 1986, Augustinus 1995, Blasco et al. 1996, Woodroffe 2002, Golbuu et al. 2003, Thampanya et al. 2006, Victor et al. 2006).

Mangroves supply a number of protective ecosystem services to surrounding communities. Coastal mangrove forests function as an important physical buffer, protecting coastal zones from erosion, extensive wave action, and flooding during tropical storms and hurricanes (Field 1998, Ellison 2000, Danielsen et al. 2005, Kar 2005, Granek and Ruttenberg 2007). As oceanic storms increase in frequency and intensity with warming sea surface temperatures (Williams 2005), the importance of mangroves is expected to increase (Table 1.1). 
Table 1.1. Benefits and threats to mangrove ecosystems.

\begin{tabular}{|l|l|}
\hline \multicolumn{1}{|c|}{ Benefits } & \multicolumn{1}{|c|}{ Threats } \\
\hline Coastal protection & Shrimp aquaculture \\
Carbon stocks & Construction of tourist resorts \\
High productivity & Lumber \\
Nursery grounds & Urbanization \\
Sediment traps & Agriculture runoff \\
-Buffer coral and seagrass communities & \\
Pollution reduction & \\
& \\
\hline
\end{tabular}

Mangrove forests serve integral ecological functions in tropical coastal zones (Mumby et al. 2004), yet damage to and loss of mangrove forests has been extensive worldwide, with an estimated loss of 1-2\% per annum (Crooks \& Turner 1999, Duke et al. 2007). Mangrove ecosystems may completely disappear from certain regions within the next 100 years (Duke et al. 2007). Coastal development that removes mangrove habitat is likely to impact adjacent nearshore coral reefs through sedimentation, nutrient loading, and changes in reef fish populations.

As communities and managers became aware of the long-term impacts of mangrove loss, interest in mangrove restoration has increased substantially. However efforts to mitigate mangrove loss with restoration have resulted in limited success (Primavera and Esteban 2008, Chen et al. 2012, Winterwerp et al. 2013). Restoration will become necessary as these coastlines begin to erode without mangrove forest protection.

One of the main reasons mangrove restoration is unsuccessful, is due to the knowledge gap in mangrove ecosystem dynamics (Salmo et al. 2013, Ye et al. 2013). 
According to a literature review of mangrove restoration, successful rehabilitation of mangrove systems suggests broadening the focus beyond planting seedlings to whole mangrove ecosystem (e.g. hydrology, nutrient levels, wave energy) (Dale et al. 2014).

Turneffe Atoll, east of the Meso-American Barrier Reef (in the Caribbean Sea), is undergoing significant land development with implications for marine habitats in the region. This trend is representative of declining mangrove cover throughout the Caribbean and solutions to the current situation on the Atoll could provide a framework for similar conservation and restoration projects in the region. The historical and recent development on Turneffe provides an opportunity to quantify the effects of mangrove clearing on coastline erosion, and to identify the ecological variables that affect natural recolonization, and likely restoration success, of mangroves following anthropogenic disturbance.

The goals of this thesis project are to: 1) examine erosion rates within coastal fringing red mangrove ecosystems following mangrove clearing and compare these rates to accretion rates in intact mangroves (Chapter 2); and 2) investigate the abiotic factors influencing mangrove seedling survival and regeneration of naturally colonizing red mangroves, Rhizophora mangle, in historic mangrove habitat after anthropogenic clearing (Chapter 3). 


\section{CHAPTER 2: EROSION OF COASTAL SEDIMENT RESULTING FROM ANTHROPOGENIC MANGROVE CLEARING}

\section{INTRODUCTION}

Mangrove forests serve integral ecological functions in tropical coastal zones (Mumby et al. 2004), yet damage to and loss of mangrove forests has been extensive worldwide (Crooks and Turner 1999). Mangrove forests are rapidly being cleared and converted for real estate speculation, construction of tourist resorts, agricultural land reclamation and other coastal development; shrimp aquaculture; and to a lesser extent, collection of lumber (Kaly et al. 1997, Stevenson 1997, Valiela et al. 2001). Mangrove forest loss due to anthropogenic clearing has occurred at an alarming rate $(-1 \%$ annually in the 1980's [FAO 2003]; -0.66\% annually between 2000-2005 [FAO 2007]) resulting in a significant decrease in global mangrove forest cover (estimated losses of up to $35 \%$ during the last two decades of the $20^{\text {th }}$ century [Valiela et al. 2001]). Some researchers project a complete loss of this ecosystem type from certain regions within the next 100 years (Duke et al. 2007).

Mangroves play a key role in ecological functioning of adjacent nearshore habitats and provide a number of ecosystem services to surrounding communities. Coastal mangrove forests function as an important physical buffer, protecting coastal zones from erosion, extensive wave action, and flooding during tropical storms and hurricanes (Field 1998, Ellison 2000, Danielsen et al. 2005, Kar 2005, Granek and Ruttenberg 2007). As oceanic storms increase in frequency and intensity with warming sea surface temperatures (Williams 2005), the importance of mangroves is expected to increase. 
Coastal mangroves along tropical shorelines are an important interface between land and sea. Mangroves serve as sediment "traps" catching terrestrial sedimentation and preventing it from smothering subtidal coral reefs, thereby filtering terrestrial runoff before it reaches coastal marine ecosystems (Bird 1971, Wolanski and Ridd 1986, Augustinus 1995, Blasco et al. 1996, Woodroffe 2002, Golbuu et al. 2003, Thampanya et al. 2006, Victor et al. 2006). Reported rates of accretion in mangroves vary by geographic location, ranging from -8.2 off of North Queensland, Australia (Spencely 1982) to +10.0 to $+11.0 \mathrm{~mm}$ year $^{-1}$ in Cairns, Queensland, Australia (Bird and Barson 1977; Spencely 1982). Therefore, coastal development that removes mangrove habitat is likely to impact adjacent nearshore coral reefs through sedimentation, nutrient loading, and changes in reef fish populations.

This study examines erosion within coastal fringing red mangrove (Rhizophora mangle) ecosystems following mangrove clearing and compares this to accretion in intact mangroves on Turneffe Atoll, Belize. The hypothesis for this study is: sediment erosion in mangrove forest ecosystems is higher in areas with cleared mangroves and fringing reefs with gaps compared to areas with intact mangroves and intact fringing reefs.

\section{$\underline{\text { METHODS }}$}

Study Site

The study was conducted on Turneffe Atoll off the Caribbean coast of Belize. Turneffe Atoll is a carbonate atoll with little or no allochthonous sediment input; sediment in the mangroves is autochthonous, derived from accumulation of biogenic material, primarily mangrove subsurface peat with lenses of calcareous sand (McKee et 
al. 2007). The coastline of Turneffe Atoll is characterized by open coast fringing $R$. mangle (red mangrove) trees, except in locations where mangroves were removed for development and/or agriculture. The submerged vegetation in front of the study sites is dominated by Thalassia testudinum (turtle grass). Five locations were sampled along the east coast of Turneffe Atoll with each study site consisting of paired intact (+mangrove) and cleared (-mangrove) mangrove areas. All study sites were along the open coast and located within a $15 \mathrm{~km}$ stretch of coastline (Figure 2.1 and Table 2.1). Wave energy is comparable within each pair. The distance between the mangrove or cleared shoreline and the fringing reef and the continuity of the fringing reef are consistent within pairs but variable among sites. Both the distance and continuity of fringing reef can influence wave energy reaching the shoreline.

The following criteria were used for site selection: 1) at least $75 \mathrm{~m}$ along-shore length of cleared $R$. mangle adjacent to stretches of at least $100 \mathrm{~m}$ of intact $R$. mangle habitat; and 2) $>2 \mathrm{~km}$ from major human development to reduce potential sources of anthropogenic nutrients and sediment. The cleared mangrove areas ranged from 75 to $250 \mathrm{~m}$ in length along the shore and ranged from recent (within 2 years of study onset) to historic (40-200 years prior) clearings. 


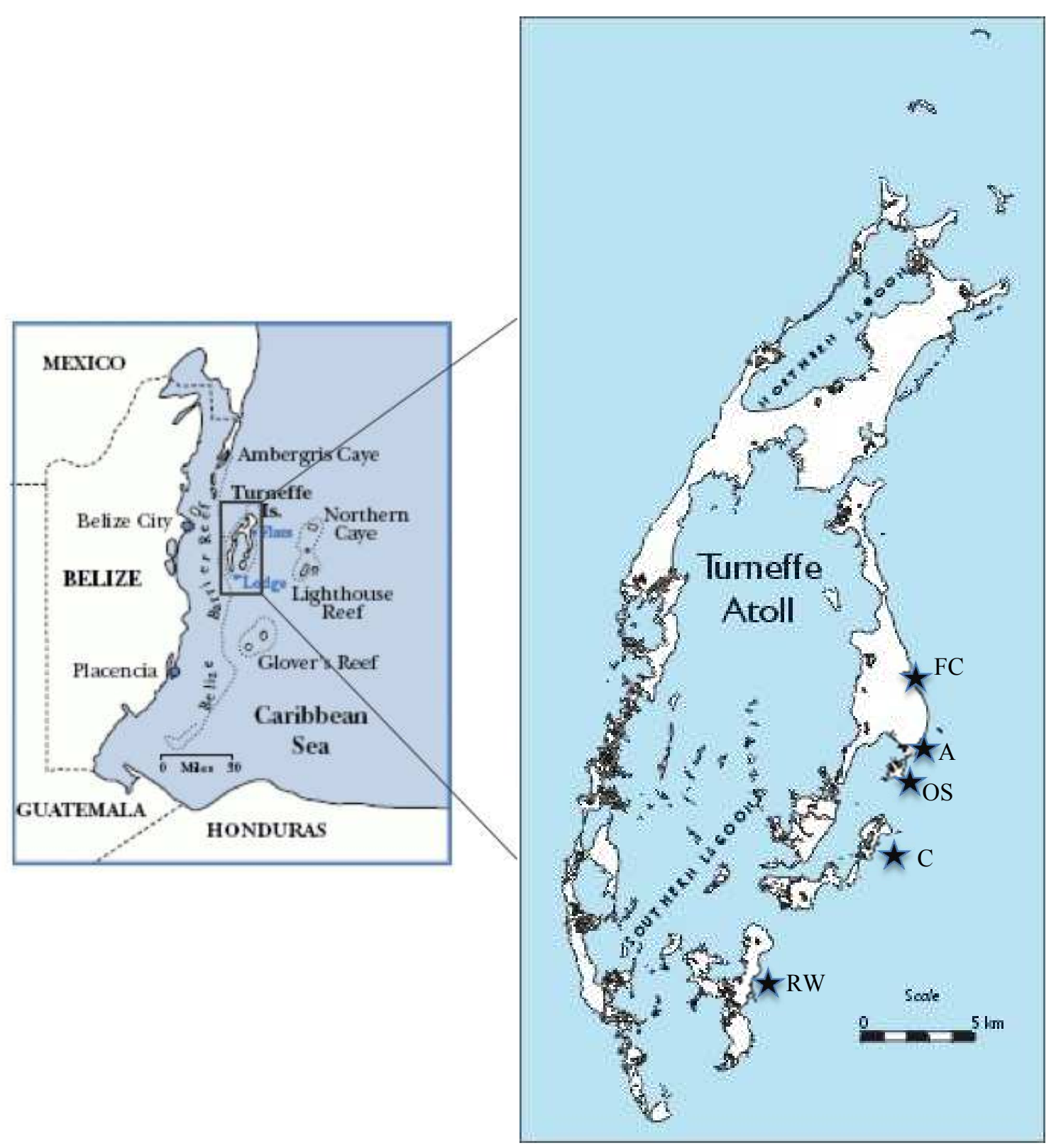

Figure 2.1. Location of study area with sites marked. Sites include from north to south Fisherman's Cut (FC), sandy sites Airport (A), Oceanic Society (OS), Calabash (C), and Ropewalk (RW).

Areas with intact mangroves were characterized by submerged prop roots colonized with sponges, epibiotic algae, tunicates and anemones. Recently cleared 
mangrove areas retained some structure from the submerged decaying prop roots; the soil was "muddy" with roots throughout. Historically cleared areas had little to no submerged decaying prop roots, with soil consisting of coarse sand with seagrass moving into former mangrove habitat.

Cleared areas have sparsely dispersed settlement of seedlings ( $\sim 1$ seedling per $\left.\mathrm{m}^{2}\right)$ compared to the adjacent intact mangrove forest ( $\sim 8$ seedlings per $\mathrm{m}^{2}$ ) (Figure 2.2). The cleared areas lack forest density and structure. The mangroves settled in cleared areas are "dwarfed" ( 1 $\mathrm{m}$ tall) relative to individuals in intact areas (up to $4 \mathrm{~m}$ tall).

Additional anthropogenic disturbances impacted two sites during the study period (in 2009). In the intact mangrove area at Airport, a section of mangroves were cleared and dredging was conducted for condominium development. Two erosion pins were lost during the clearing. Adjacent to the cleared site at Ropewalk, dredging was conducted increasing suspended sediment in the cleared area. 

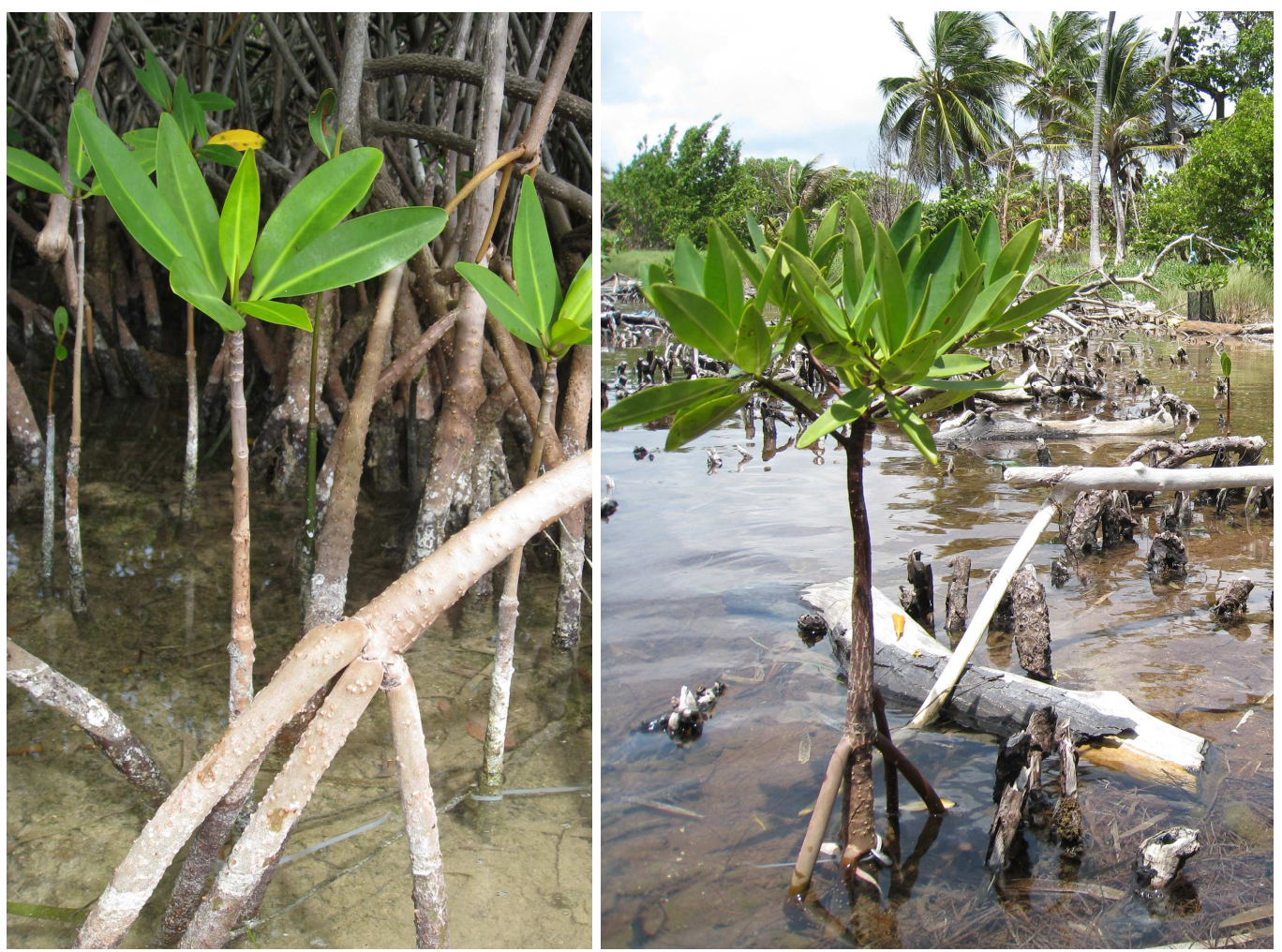

Figure 2.2. Seedling density at Fisherman's Cut intact (left) and cleared (right).

\section{Erosion Pins}

Tubes of PVC piping with $2.5 \mathrm{~cm}$ external diameter $\mathrm{x} 1.5 \mathrm{~m}$ long tubes were used as erosion pins to quantify sediment accretion or erosion. Erosion here refers to both sediment leaving the system and compaction (Cahoon et al. 2003). At each site, five erosion pins were deployed behind areas cleared of mangroves and five pins were deployed at the same distance from the seaward edge of the mangroves behind intact forest. At all sites except Calabash, these pins were placed during a previous study by $\mathrm{S}$. Waddington and E. Granek. The protocol employed for placing the erosion pins was adopted from dune studies by Moreno-Cassola (1986) and Arens and Slings (2004). The research plots are located near fishing camps, developed resorts, homes, and a Belize 
National Coast Guard Station. The current method of measuring mangrove sediment accretion/erosion, Surface Elevation Table (SET) (Cahoon et al. 2003) equipment was infeasible at the study site due to the risk of equipment removal by transient fishers. Therefore, a low-tech, low-cost technique mimicking SET for data collection was employed.

The $1.5 \mathrm{~m}$ long PVC piping tubes were buried in the substrate with $60 \mathrm{~cm}$ of tube remaining above ground. Sediment accretion or erosion rates were quantified by measuring the length of tube above the sediment at 0-, 6-, 12- and 24- months post deployment. The PVC tubes were measured to the nearest $0.1 \mathrm{~cm}$ from the top of the tube to the sediment on the ocean and front terrestrial sides. Each pin was gently pulled upward and pushed downward to confirm that pins were secure and not floating in the hole. All pins were secure at each sampling period.

\section{Data analysis}

The five erosion pins per plot were pooled and examined at 12- and 24- months post deployment. Changes in sediment levels between intact and cleared mangrove plots and among sites were examined using a two-way ANOVA after confirming data met assumptions of variance homogeneity (Levene's Test) and normal distribution (ShapiroWilk Test). A multi-factor ANOVA was used to examine whether sedimentation rates differed by continuity of adjacent reef structure, site, and mangrove condition (intact vs. cleared). 


\section{$\underline{\text { RESULTS }}$}

Sediment accreted $(\mathrm{M}=3.83 \mathrm{~mm}, \mathrm{SD}=2.12)$ at the intact mangrove plots but eroded $(\mathrm{M}=-7.30 \mathrm{~mm}, \mathrm{SD}=7.27)$ at the cleared mangrove plots over the course of the study (Table 2.1). Between June 2008 and June 2010, sedimentation differed between intact and cleared areas $(F=79.52, p<0.001)$, across sites $(F=6.41, p<0.001)$, and the differences in sedimentation between intact and cleared areas varied by site $(\mathrm{F}=9.57$, $\mathrm{p}<0.001)$ (Figure 2.3).

In cleared areas, sedimentation rates were greater at sites with gaps in the adjacent fringing reef (Airport and Oceanic, $\mathrm{M}=-15.05 \mathrm{~mm}$ ) than at sites with continuous fringing reef $(\mathrm{M}=-1.90 \mathrm{~mm}, \mathrm{~F}-18.59, \mathrm{p}<0.001)$. In intact mangrove forest, accretion did not differ between sites with reef gaps $(\mathrm{M}=4.11 \mathrm{~mm})$ and sites with continuous reef $(\mathrm{M}$ $=3.65 \mathrm{~mm})$. Sediment accumulation was greater in intact than cleared areas $(\mathrm{F}=81$, $\mathrm{p}<0.001)$ and the effects of reef continuity on sediment accumulation/loss varied by mangrove condition $(\mathrm{F}=32.33, \mathrm{p}<0.001)$. 
Table 2.1. Fringe reef structure, anthropogenic disturbances during study period, and mean accretion and erosion rates at cleared and intact plots for each site (Year $1=$ June 2008 to June 2009, Year 2 = June 2009 to June 2010).

\begin{tabular}{|c|c|c|c|c|c|c|}
\hline \multicolumn{2}{|l|}{ Site } & Airport & Calabash & Fisherman's & Ropewalk & Oceanic \\
\hline \multicolumn{2}{|l|}{ Fringe Reef Protection } & Few gaps & Complete & Complete & Complete & Gaps \\
\hline \multicolumn{2}{|l|}{ Dominant sediment type } & Sandy & Sandy & Detrital mud & Sandy & Sandy \\
\hline \multicolumn{2}{|l|}{ Years since clearing } & 4 & $\sim 40$ & 2 & 8 & $\sim 200$ \\
\hline \multicolumn{2}{|l|}{ Anthropogenic disturbances } & $\begin{array}{c}\text { Dredging \& } \\
\text { clearing } 2009\end{array}$ & None & None & $\begin{array}{l}\text { Dredging } \\
2009\end{array}$ & None \\
\hline \multirow[t]{2}{*}{$\begin{array}{l}\text { Mean soil accretion }(\mathrm{mm}) \\
\text { in intact plots }\end{array}$} & $\begin{array}{c}\text { Year } \\
1\end{array}$ & +1.62 & +5.33 & +2.04 & +0.73 & +3.58 \\
\hline & $\begin{array}{c}\text { Year } \\
2\end{array}$ & +2.08 & +4.89 & +4.92 & +1.13 & +6.14 \\
\hline \multirow[t]{2}{*}{$\begin{array}{l}\text { Mean soil erosion }(\mathrm{mm}) \\
\text { cleared areas }\end{array}$} & $\begin{array}{c}\text { Year } \\
1\end{array}$ & -10.7 & -0.35 & -2.3 & -0.25 & -6.32 \\
\hline & $\begin{array}{c}\text { Year } \\
2\end{array}$ & -16.73 & -2.06 & -3.56 & -0.09 & -20.18 \\
\hline
\end{tabular}




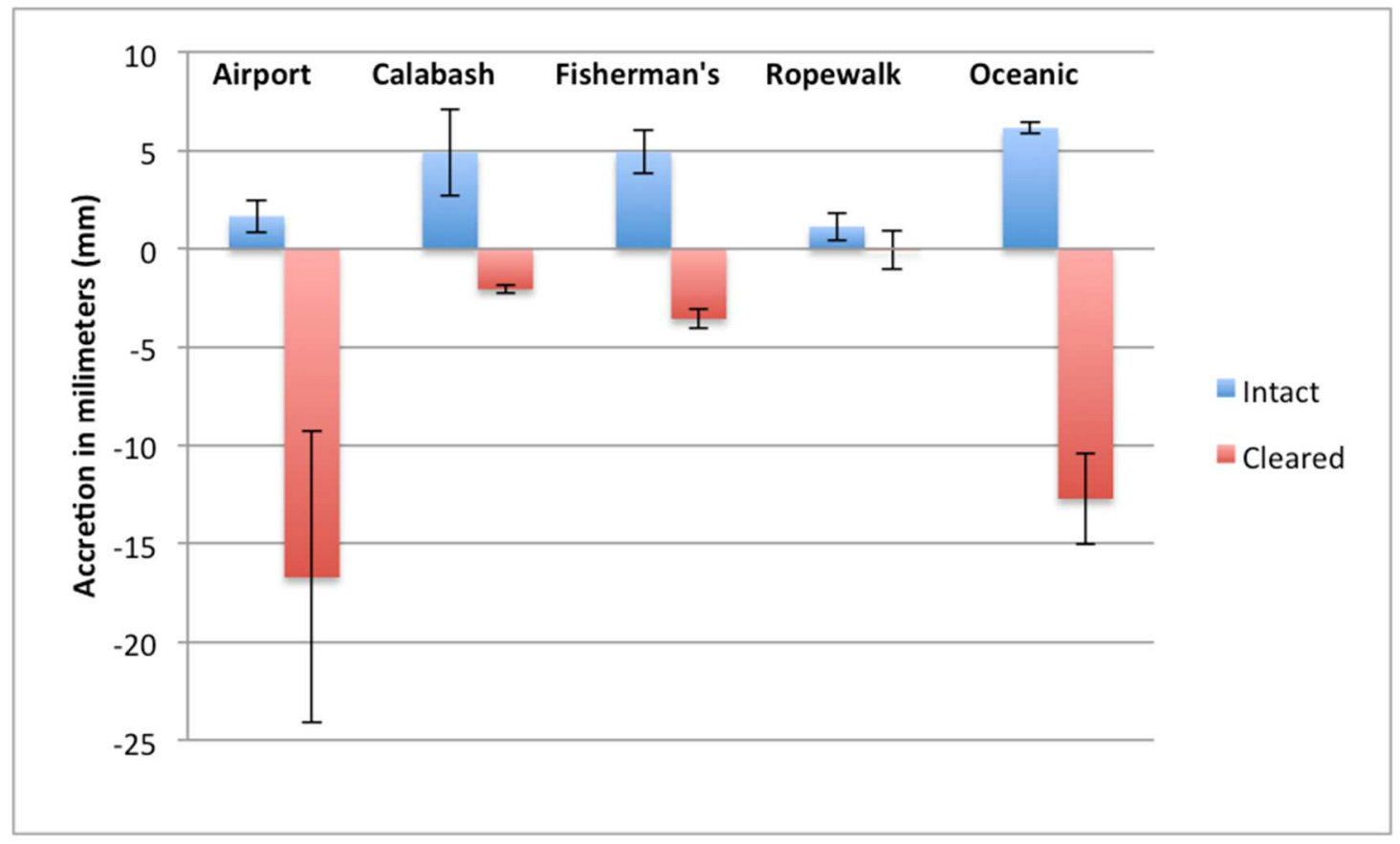

Figure 2.3. Accretion/erosion (in $\mathrm{mm}$ ) of sediment between June 2008 and June 2010 at five study sites on Turneffe Atoll.

\section{$\underline{\text { DISCUSSION }}$}

Coastal mangrove forests function as important physical buffers protecting coastlines from erosion and nearshore marine ecosystems from sedimentation. When mangroves are anthropogenically thinned or removed, this function is reduced or eliminated. Whereas intact mangroves on Turneffe Atoll accreted sediment, cleared areas adjacent to the intact mangroves suffered sediment erosion over the same time period. Cleared sites with discontinuous fringing reef offshore suffered higher erosion rates than sites with continuous fringing reefs. These data add to the growing body of evidence 
quantifying the ecological function provided by coastal mangrove forest habitat to prevent coastal erosion.

Natural variability in fringing reef structure can affect sediment patterns (Table 2.1). Study sites with (50-100 $\mathrm{m}$ alongshore gaps in the fringing reef (Airport and Oceanic), had higher erosion rates $(-16$ to $-20 \mathrm{~mm})$ in the cleared areas. Gaps in the fringing reef reduce protection from incoming wave action (Kunkel et al. 2006, Sheppard 2005) resulting in higher erosion rates when mangroves are removed. On the other hand, Calabash and Fisherman's have extensive and continuous reef protection and are located further from the reef (Fisherman's is $\sim 500 \mathrm{~m}$ and Oceanic is $\sim 100 \mathrm{~m}$ inshore); these sites experienced lower erosion rates in the cleared areas $(2-3.5 \mathrm{~mm})$.

Anthropogenic disturbance events such as dredging can reduce erosion rates at cleared mangrove sites due to sediment resuspension. At Ropewalk, dredging increased sediment suspension for 4 months during the summer of 2009; I hypothesize that this increased sediment suspension during dredging led to increased sediment deposition at the cleared area, counteracting the erosion (Figure 2.3).

The sites on Turneffe Atoll have variable sediment dynamics due to variability in the fringing reef and the resultant wave energy in the mangroves and additional anthropogenic disturbances at certain sites. The erosion reported likely results from a combination of peat collapse over time due to decomposition of organic material and compaction of the substrate, both of which contribute to loss in surface elevation (Cahoon et al. 2003).

Reported rates of accretion in mangroves vary by geographic location, ranging 
from -8.2 off of North Queensland, Australia (Spencely 1982) to +10.0 to $+11.0 \mathrm{~mm}$ year $^{-1}$ in Cairns, Queensland, Australia (Bird and Barson 1977; Spencely 1982). This study reported rates of accretion and erosion fall within this range. However, to date, sediment accretion and erosion research in mangrove ecosystems has not directly compared intact and cleared mangrove areas. McKee et al. (2007) and McKee (2011) suggest that mangrove removal would lead to land and habitat stability losses due to a cessation of soil accretion, yet continued decomposition, compaction and erosion processes. Within fringe mangroves McKee et al. (2007) found surface subsidence rates due to decomposition and physical compaction in Twin Cays, Belize at a rate of $-5.0 \mathrm{~mm}$ year $^{-1}$ and vertical accumulation in fringe mangroves in Belize of between 8 and $9 \mathrm{~mm}$ year $^{-1}$. Yet field data quantifying the effects of mangrove clearing on sediment retention are a data gap in the current literature. The data from erosion pins provide the first quantitative evidence of erosion in cleared areas at sites that accrete sediment when mangroves are present.

The significant sediment accumulation recorded in the intact mangroves may be enhanced by benthic mat development and belowground accumulation of roots resulting in vertical sediment accretion in Caribbean mangrove ecosystems (McKee 2011). McKee (2011) reported low accretion rates in Belizean fringing mangroves but subsurface root growth accounting for $8.8 \mathrm{~mm}$ year $^{-1}$ vertical change, with an overall elevation change of $4.1 \mathrm{~mm}$ year $^{-1}$ after accounting for compaction, decomposition and hydrodynamics. Given that the accumulation in the intact mangrove areas was comparable, I hypothesize similar processes at work. 
This research finds that removal of mangrove vegetation leads to sediment loss and increased submergence and land loss. This loss is exacerbated where fringing reef is discontinuous. Erosion rates following mangrove clearing can vary as a result of additional disturbance events. These findings highlight the need for careful consideration of the subtidal features adjacent to sites slated for mangrove removal or transformation. Such information may prove useful in identifying areas that are most vulnerable to erosion following mangrove removal, a potential tool for determining where mangrove clearing is most likely to impact coastal protection. 


\section{CHAPTER 3: NUTRIENTS ENHANCE RHIZOPHORA MANGLE SEEDLING REGENERATION, TURNEFFE ATOLL, BELIZE}

\section{INTRODUCTION}

Mangrove forests are being cleared at a rate of $\sim 1 \%$ annually (FAO, 2003) and the past few decades have seen a significant decrease in global mangrove forest cover (estimated losses of up to $\sim 35 \%$ during the last two decades of the $20^{\text {th }}$ century [Valiela et al. 2001]). Mangrove forests are being converted to facilitate the development of tourist resorts, agricultural land reclamation, real estate speculation, and entrepreneurial endeavors such as shrimp aquaculture, charcoal production and to a lesser extent, collection of lumber (Kaly et al. 1997; Stevenson et al 1999; Valiela et al. 2001).

Coastal mangrove forests provide a number of ecosystem services historically to communities near tropical coastal systems. Mangrove forests play a valuable role in the global carbon balance because of their carbon sequestration potential (Kristensen et al. 2008). Coastal mangrove forests function as an important physical buffer protecting coastal zones from erosion, extensive wave action, and flooding during tropical storms and hurricanes (Field 1998, Ellison 2000, Danielsen et al. 2005, Kar 2005, Granek \& Ruttenberg 2007). As oceanic storms increase in frequency and intensity with warming sea surface temperatures (Williams 2005), the importance of mangroves is expected to increase. Coastal mangroves are also important as sediment "traps" catching terrestrial sedimentation and preventing it from smothering seagrass beds and coral reefs subtidally and filtering terrestrial runoff before reaching coastal marine ecosystems (Golbuu, et al. 2003). Therefore, disturbance events that remove mangrove habitat are likely to impact 
nearshore coral reefs through sedimentation, nutrient loading, and changes in reef fish populations as well as human populations through reduction in fish catch. Shrimp aquaculture has been used as a source of poverty alleviation and livelihood creation. Unfortunately, the environmental and socio-economic effects of these initiatives have been detrimental to communities (Valiela et al. 2001).

Realization of the wide range of ecological and socio-economic benefits provided by mangrove ecosystems, has led governments and stakeholders to protect and restore these unique ecosystems. However, many rehabilitation and restoration projects have not considered the environmental conditions necessary for successful restoration; as a result, many projects have failed to achieve their goals (Elster 2000, Lewis 2005). Restoration has been undertaken for various reasons, such as for commercial purposes, restoring fisheries and wildlife habitats (Walters et al. 2008) and shoreline protection (Saenger \& Siddiqi 1993, Mazda et al. 1997). Mangrove restoration projects cost thousands to millions of dollars. In the Philippines, a two-decade project to restore mangrove forests resulted in a 10-20\% long-term survival rate, at the cost of millions of dollars because the project used inappropriate species and poor site selection (Primavera \& Esteban 2008, Samson \& Rollon 2008).

Of the hundreds of mangrove replanting efforts carried out in coastal areas, only a small number have been monitored or studied by ecologists (Kentula 2000). The lack of monitoring makes it difficult to identify factors contributing to success or failure of restoration projects (Bosire et al. 2008; Lewis 2000). Some of the issues mentioned by Field (1998) and Thampanya et al. (2006) include neglecting to consider species ecology 
and site selection; poor and short term management practices; differing expectations by various stakeholders; and lack of collaboration.

Mangrove rehabilitation approaches including planting propagules and allowing natural regeneration have had limited success in historic mangrove areas (Field 1998). To facilitate both natural regeneration and improve success of future restoration projects, it is necessary to understand the factors limiting successful seedling establishment and regeneration. Lovelock et al. (2007) found that nutrient enrichment is an important factor contributing to mangrove re-establishment in estuaries on the North Island of New Zealand. The development on Turneffe offers an urgent and timely opportunity to assess the immediate and longer-term effects of mangrove clearing and identify the ecological variables that affect natural recolonization of mangroves, particularly following anthropogenic disturbance.

To inform future restoration projects, the primary goal of this study was to understand the abiotic factors influencing seedling survival and regeneration of naturally colonizing red mangroves, Rhizophora mangle, in historic mangrove habitat after anthropogenic cleared.

This study tested the following hypotheses:

- Colonized seedling mortality is significantly lower in intact areas versus anthropogenically cleared mangrove habitats.

- Adding nutrients and wave protection to mangrove seedlings following anthropogenic clearing increases seedling growth and fitness.

- Seedlings growing in areas with detrital mud substrate grow faster then seedling in sandy or coral rubble substrate. 


\section{METHODS}

\section{$\underline{\text { Study Site }}$}

Turneffe Atoll, east of the Meso-American Barrier Reef (in the Caribbean Sea), is undergoing significant land development with implications for marine habitats in the region. This trend is representative of declining mangrove cover throughout the Caribbean. Understanding drivers of success and failure in seedling regeneration can inform conservation and restoration projects in the region. The historical and recent development on Turneffe and the natural seedling regeneration that has occurred provide an opportunity to identify the ecological variables that affect natural recolonization, and likely restoration success, of mangroves, particularly following anthropogenic disturbance.

The study was conducted at five paired study sites arrayed along a $39 \mathrm{~km}$ stretch of coastline along the East side of Turneffe Atoll, Belize (Fig 3.1). Turneffe Atoll is a peat-based, 92-ha archipelago, $12 \mathrm{~km}$ off shore $\left(16^{\circ} 50^{\prime} \mathrm{N}, 88^{\circ} 06^{\prime} \mathrm{W}\right)$. The atoll receives no terrigenous inputs of freshwater or sediments from the mainland (Macintyre \& Toscano 2004). Each site consisted of a pair including one area of intact and one area of cleared mangroves. 


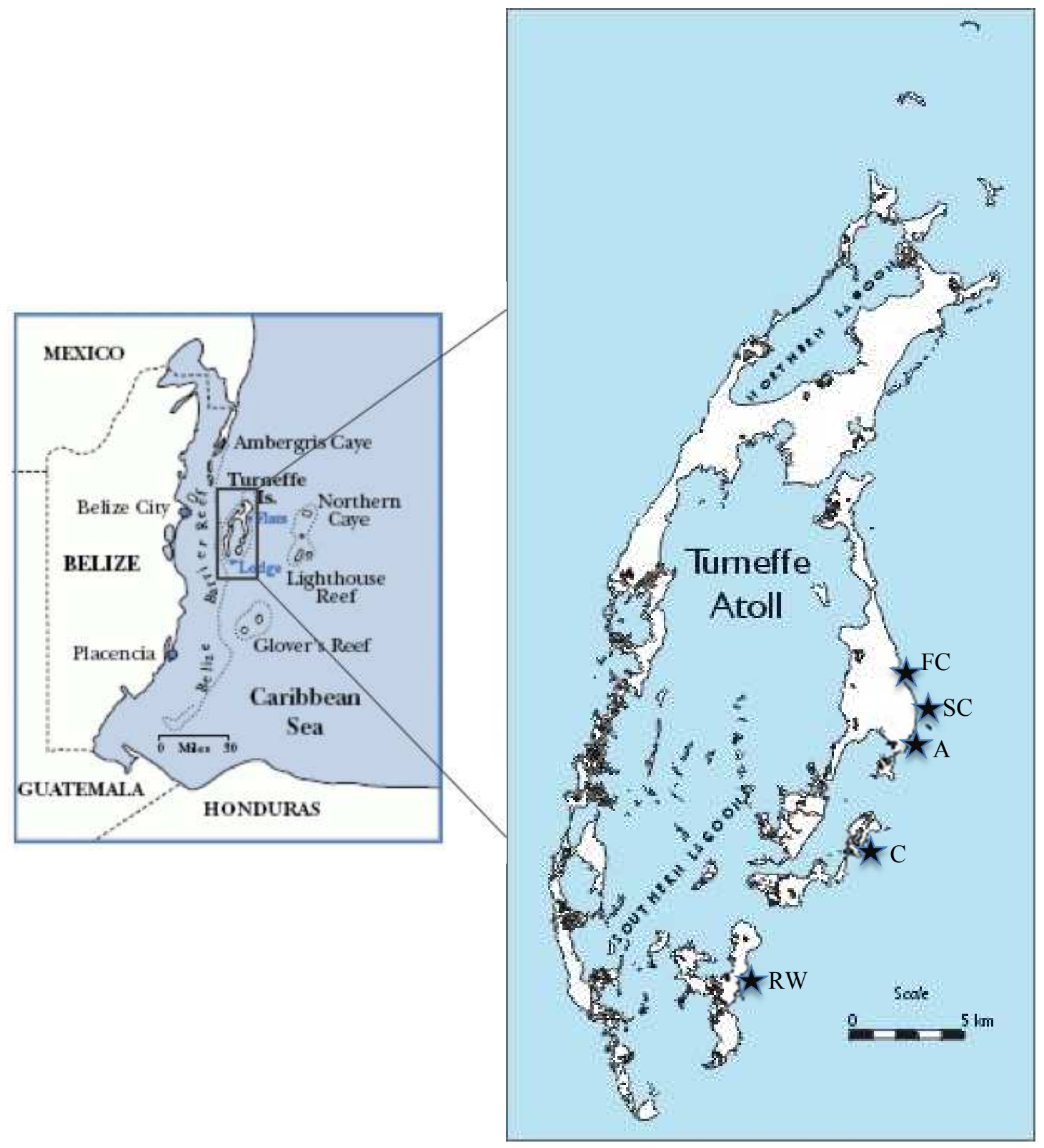

Figure 3.1. Location of study area with sites marked. Sites include from north to south detrital mud site Fisherman's Cut (FC), coral rubble site Soldier's Caye (SC), sandy sites Airport (A), Calabash (C), and Ropewalk (RW).

Cleared sites were selected from areas where mangroves had been anthropogenically cleared, seedlings had naturally colonized, yet forest regeneration had not occurred. All sites met the following criteria: (1) ecosystem was characterized by $R$. 
mangle trees; (2) a minimum of $75 \mathrm{~m}$ stretch of cleared coastline adjacent to a stretch of at least $100 \mathrm{~m}$ of intact Rhizophora mangle (L.); (3) located at least $10 \mathrm{~km}$ from major human development to exclude potential sources of anthropogenic nutrients; and (4) similar exposure to wave action within each paired cleared and intact area. Intact mangrove habitat was characterized by fringing mangrove forest with a canopy height of 3 to $7 \mathrm{~m}$ and was composed of $R$. mangle exclusively at the seaward edge. All sites had a $\sim 0.5 \mathrm{~m}$ tidal range. Cleared areas ranged from 75 to $250 \mathrm{~m}$ in along-shore length, and clearing was either recent (within 8 yrs of study deployment) or historic ( $>40$ yrs prior). The sites had three different substrate types: one coral rubble site (Soldiers, very little sediment, older disturbed site), one detrital mud substrate site (Fisherman's, cleared within the last 2 years), and three sandy substrate with seagrass sites (1 cleared about 40yrs prior (Calabash) and 2 cleared within 10 years (Airport and Ropewalk) (Table 3.1). Recently cleared sites (Airport and Fisherman's) had some remaining 3dimensional subtidal prop root structure; historically cleared sites were devoid of root structure above the substrate. Fisherman's cut was cleared 2 years prior to this study. The dark muddy layers of organic material in the cleared area at Fisherman's was still intact, providing nutrients to the seedlings throughout the study, similar to the intact areas (Figure 3.2). Remaining prop roots from clearing provided structure in the soil; these may have remained due to the natural protection from a complete fringing reef. Also Fisherman's had a natural wave protection from a small island $(2 \times 6 \mathrm{~m})$ of mangroves remaining from the clearing (Table 3.1). Airport was cleared 4 years before the study; when the study began, as with Fisherman's, the remaining prop roots were still in the ground. Within six months these remaining prop roots had all been washed away at 
Airport possibly due to the lack of protection from the gaps in the fringing reef. All cleared sites had naturally settled mangrove seedlings .

Table 3.1. Site description and locations of treatment application.

\begin{tabular}{|l|c|c|c|c|}
\hline Site & $\begin{array}{c}\text { Approximate Number of } \\
\text { Years Since Clearing in } \\
\mathbf{2 0 0 8}\end{array}$ & Substrate & $\begin{array}{c}\text { Natural Wave } \\
\text { Protection }\end{array}$ & $\begin{array}{c}\text { Treatments } \\
\text { Applied }\end{array}$ \\
\hline Calabash & $\sim 40$ & Sandy & No & Yes \\
\hline Fisherman's Cut & 2 & $\begin{array}{c}\text { Detrital } \\
\text { muddy }\end{array}$ & Yes & Yes \\
\hline Ropewalk & 8 & Sandy & No & Yes \\
\hline Airport & 4 & Sandy & No & No \\
\hline Soldier's Caye & $\sim 50$ & Coral rubble & No & No \\
\hline
\end{tabular}




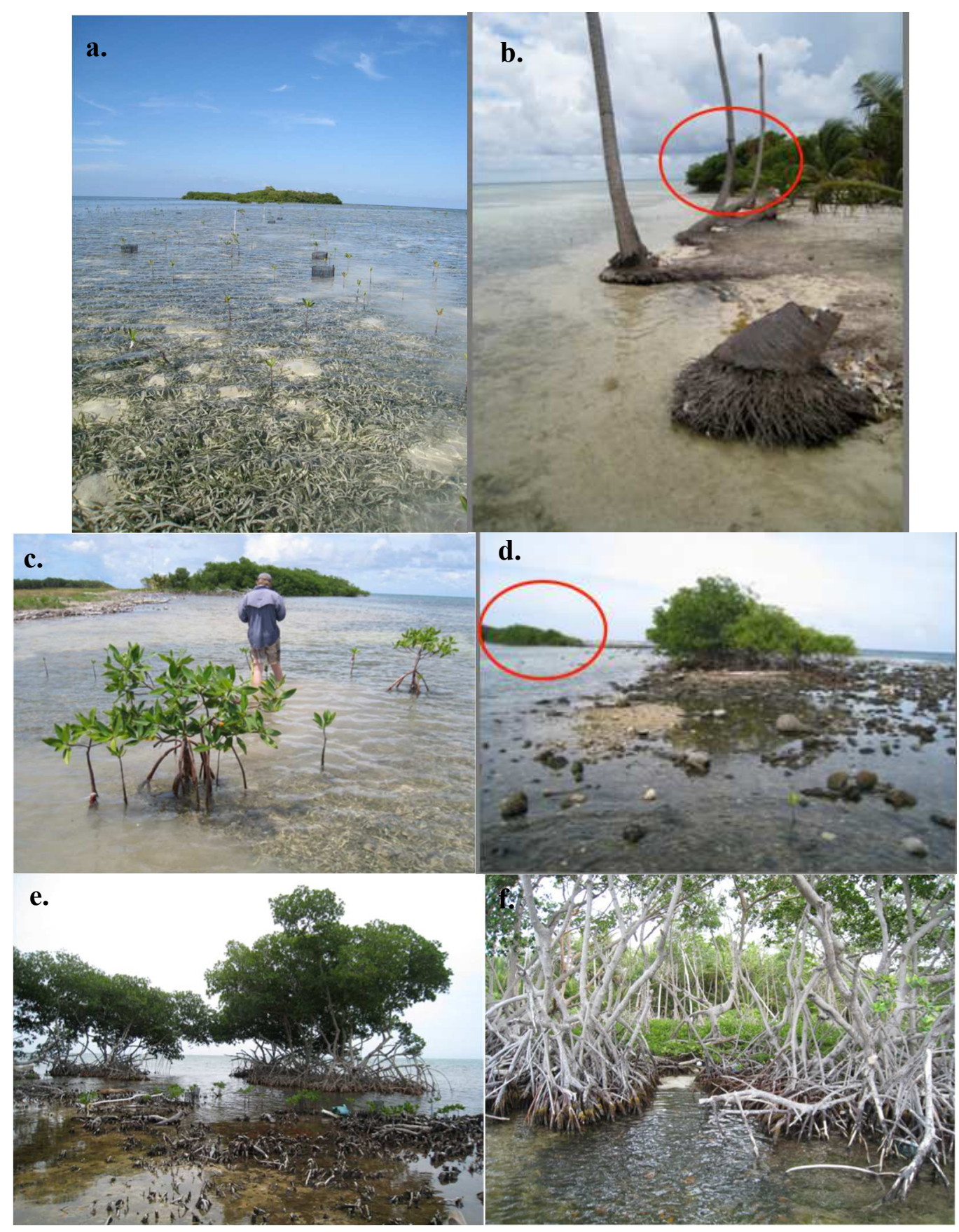

Figure 3.2. Photos of research sites: (a) Calabash with intact mangroves in background; (b) Ropewalk with circled intact mangroves; (c) Airport with intact mangroves in the background; (d) Soldiers with circled intact mangroves;(e) Fisherman's cleared area with natural protection and old prop roots remaining in sediment; and (f) Fisherman's intact mangroves. 
Anthropogenic disturbance events during study

Anthropogenic disturbances impacted two sites during the study period. In the intact mangrove area at Airport, a section of mangroves was cleared and dredging was conducted for condominium development in early 2009 (Figure 3.2). A number of seedlings in the intact area were removed during the clearing of land. At Ropewalk, dredging was conducted for four months during the summer of 2009 reaching to within $40 \mathrm{~m}$ of the research site (Figure 3.2).
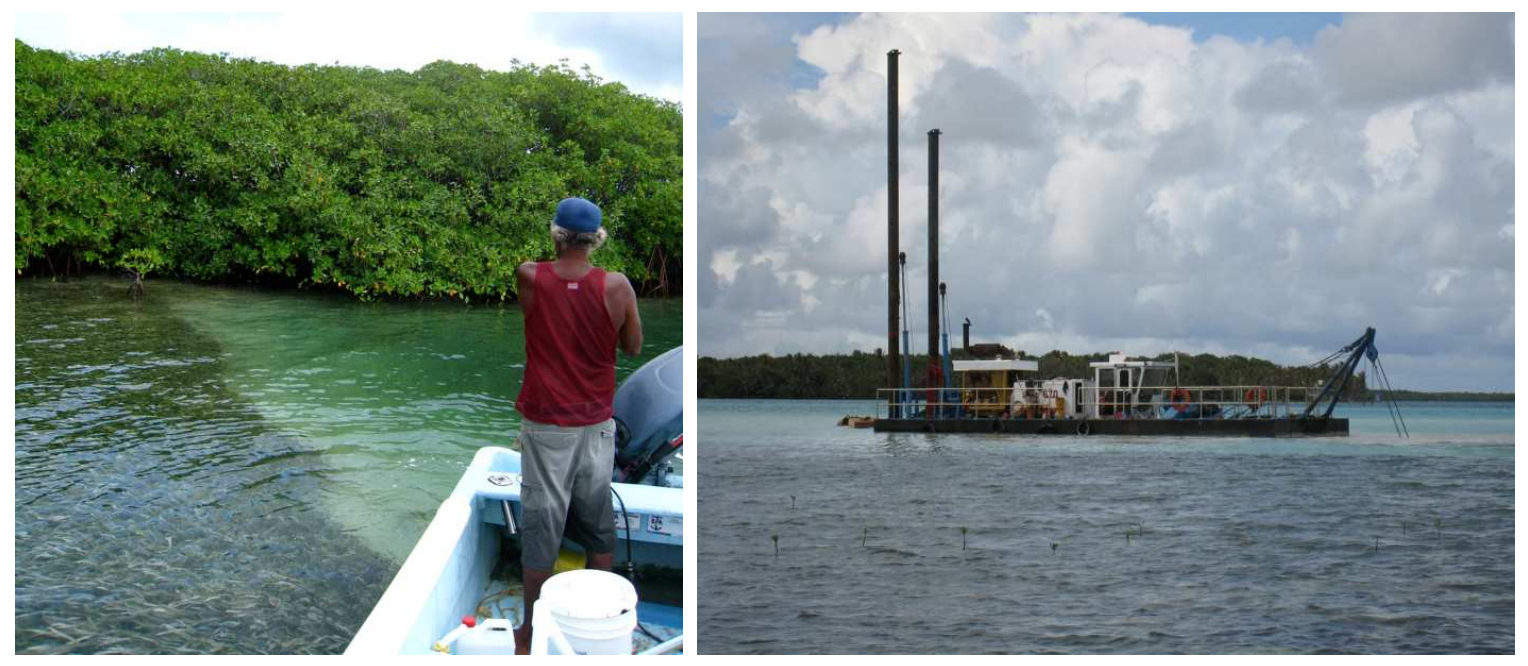

Figure 3.3. Photo of dredging at Airport (left) and Ropewalk 2009 (right).

\section{Field Observations and Sampling}

Intact vs Cleared: Mortality and Growth Parameters

The study was conducted from June 2008 to June 2010. A census of 100 seedlings at each site (50 in the intact and 50 in the cleared areas) was conducted to establish the demographics of the mangrove seedling population. Seedlings were selected based on similarity in height and structure (branches and prop roots). Seedlings were tagged with numbered aluminum tree tags and the census was conducted annually for two years. Multiple metrics of growth and fitness were measured including height, 
diameter at $20 \mathrm{~mm}$, and number of leaves, branches, prop roots and nodes on each seedling. After the initial census, presence/absence was recorded on each seedling along with the growth indicators.

\section{Seedling Growth Experiment}

In the cleared areas at three of the sites, one of six treatments was applied to 36 additional seedlings; there were 6 seedlings per treatment, blocked by site. Treatments included: nutrient, wave, nutrient/wave, control, nutrient control, and wave control (Table 3.2). Seedlings were selected based on similarity in height and structure (branches and prop roots). For the nutrient treatment, $5 \mathrm{~g}$ of 14-14-14 NPK Osmocote fertilizer was mixed with plaster of paris to create a slow release. The Osmocote cubes were bagged in mesh and placed in a hole $(7 \mathrm{~cm}$ wide $\times 30 \mathrm{~cm}$ deep), cored into the substrate at the base of the seedlings (Figure 3.4).

Table 3.2. Experimental design for treatment application.

\begin{tabular}{|l|c|c|}
\hline \multicolumn{1}{|c|}{ Treatment } & Nutrients & Wave Protection \\
\hline Control Cleared & O & O \\
\hline Control Intact & O & O \\
\hline Nutrient Control & cores, but O & O \\
\hline Wave Control & O & + (partial) \\
\hline Wave & O & O \\
\hline Nutrient & + & + \\
\hline Nutrient*Wave & + & \\
\hline
\end{tabular}


Each hole was sealed with the appropriate substrate for the site. A nutrient control treatment was deployed to assure the addition of the plaster of paris cubes did not harm the seedlings during application. For the nutrient controls, plaster of paris cubes without the Osmocote were added to seedlings using the same procedure used for nutrient treatments. Direct fertilizer application to the root zone of the trees was used because the sites were flooded at high tides. Seedlings were fertilized 3 times at 6-month intervals (June and December 2008, and June 2009). This nutrient application technique was used previously by Feller and others on Twin Cays, Belize (2007).

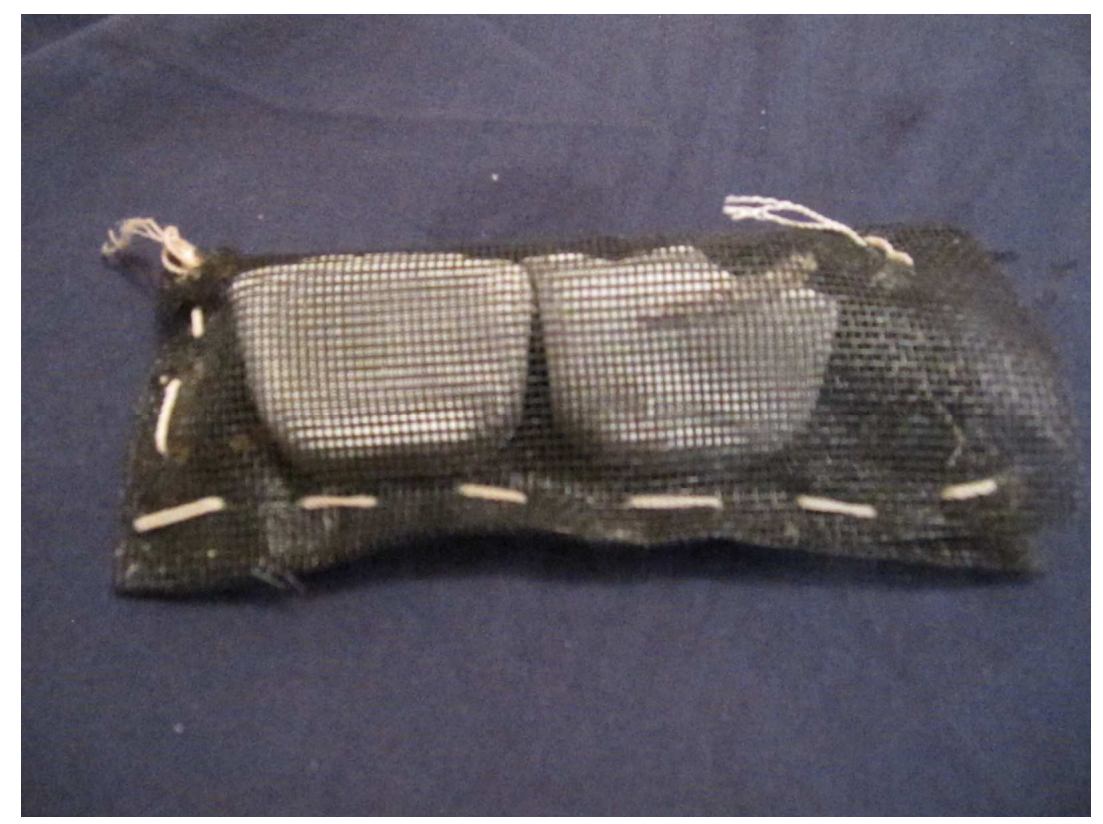

Figure 3.4. Photo of nutrient treatment: 14-14-14 NPK Osmocote set in plaster of paris cubes.

The wave protection treatment was construction of a $0.3 \mathrm{~m}$ tall Vexar mesh fence anchored around the seedlings using rebar stakes attached with zip-ties. Wave controls included mesh fences with 220 -cm diameter holes cut out. This partial wave protection 
was not a true control as it functioned similar to the wave treatment. For nutrient and wave treatments the $5 \mathrm{~g}$ of 14-14-14 NPK Osmocote fertilizer placed at the base of seedlings and a $0.3 \mathrm{~m}$ tall Vexar mesh fence anchored around the seedlings.

Treatment seedlings were separated by at least 5 meters to prevent treatments from impacting other seedlings. Seedling growth (height, diameter, change in branches, prop root numbers and leaf count) and survivorship were measured to compare treatments.

\section{$\underline{\text { Statistical Analysis }}$}

\section{Intact vs Cleared: Mortality}

An independent-samples $\mathrm{X}^{2}$ test was conducted to compare mortality between intact and cleared mangroves. Due to the dredging at the Airport and Ropewalk sites, an independent-samples $\mathrm{X}^{2}$ test was conducted to compare mortality between intact and cleared mangroves with the three remaining sites (Soldiers, Calabash, and Fisherman's).

\section{$\underline{\text { Intact vs Cleared: Growth Parameters }}$}

\section{Site vs Local}

To analyze differences in growth rates (height) between cleared and intact mangroves, the data were square-root transformed prior to analysis to meet analysis of variance (ANOVA) assumptions of equal variance and normality. A two-way ANOVA of mangrove presence (intact vs cleared) and physical location (Sites: Calabash, Soldiers, Fisherman's, Ropewalk, and Airport) on change in height over the two years was conducted. A Tukey HSD test was used to examine all possible pairwise interactions 
among variables. Diameter and nodes did not meet the variance homogeneity assumption for an ANOVA, so the data were square-root transformed and analyzed using KruskalWallis test. Nodes were calculated by dividing the number of nodes counted by the height of the seedlings to get the number of nodes per height $(\mathrm{cm})$ (higher number equals slower seedling growth). The remaining morphological data (leaves, prop roots and branches) were analyzed using a quasi-poisson Generalized Linear Model test.

\section{Sediment Type}

To analyze the differences in growth parameters according to sediment type (detrital mud, sandy, and coral rubble), data from the cleared areas were square-root transformed prior to analysis to meet analysis of variance (ANOVA) assumptions of equal variance and normality. A two-way ANOVA of sediment type (detrital mud, coral rubble, and sandy) and physical location (Sites: Calabash, Soldiers, Fisherman's, Ropewalk, and Airport) on change in height was conducted. Diameter and nodes did not meet the variance homogeneity assumption for an ANOVA, so the data were square-root transformed and analyzed using Kruskal-Wallis test. The remaining morphological data (leaves, prop roots and branches) were analyzed using a quasi-poisson GLM test.

Treatments: Seedling Growth Experiment

\section{Control vs Nutrient-Control}

To test the hypothesis that the nutrient control had no effect on seedling growth examined whether nutrient control seedlings and control seedlings had similar growth (height) rates using an independent samples t-test. Nutrient vs. nutrient control data was $\log +1$ transformed prior to data analysis to improve normality and meet homogeneity of variance assumptions. The nutrient control and control distributions were sufficiently 
normal for the purposes of conducting a t-test (i.e., skew $<|2.0|$ and kurtosis $<|9.0|$; Schmider et al. 2010). This distribution had a skewness of $0.26(\mathrm{SE}=0.61)$ and kurtosis of $1.84(\mathrm{SE}=1.22)$. Additionally, the assumption of homogeneity of variance was tested and satisfied via Levene's F test, $\mathrm{F}(1)=1.22, \mathrm{p}=0.28$.

\section{Treatment vs Sediment}

To analyze differences in growth (height) between treatments applied in the cleared areas at Ropewalk, Calabash and Fisherman's, the data were tested for homogeneity of variance using Levene's $F$ test, $F$ test $(F(3)=0.51, p=0.67)$. A two-way ANOVA of sediment type (sandy and detrital mud) and physical location (Sites: Calabash, Fisherman's and Ropewalk) on height, diameter, and nodes was conducted. A Tukey HSD test was used to examine all possible pairwise interactions among variables. The leaves and prop roots were analyzed using a quasi-poisson Generalized Linear Model test.

\section{Nutrient Wave and Nutrient vs Intact Mangrove}

To test the hypothesis that mangrove seedlings with NW and N treatments had similar growth (height) to seedlings in the intact areas, a two-way ANOVA was performed. Both NW vs. mangrove control and N vs. mangrove control data were squareroot transformed prior to data analysis to improve normality and meet homogeneity of variance assumptions. The distributions were sufficiently normal for the purposes of conducting a t-test (i.e., skew $<|2.0|$ and kurtosis $<|9.0|$; Schmider et al. 2010). The 
assumption of homogeneity of variance was tested and satisfied via Levene's F test (Nutrient $F(1)=0.34, p=0.566$; Nutrient $/$ Wave $F(1)=3.58, p=0.0702$.

\section{RESULTS}

$\underline{\text { Intact vs Cleared: Mortality }}$

Seedling mortality without disturbances (Calabash, Soldiers and Fisherman's) was $31 \%$ in the cleared areas and $13 \%$ in the intact areas $\left(X^{2}:(1, n=305)=14.60\right.$, $\mathrm{p}<0.00015$ ). Seedling mortality including sites with disturbances was $26 \%$ in the cleared areas and $32 \%$ in the intact areas $\left(\mathrm{X}^{2}:(1, \mathrm{n}=493)=2.33, \mathrm{p}=0.1268\right)$ (Figure 3.5).

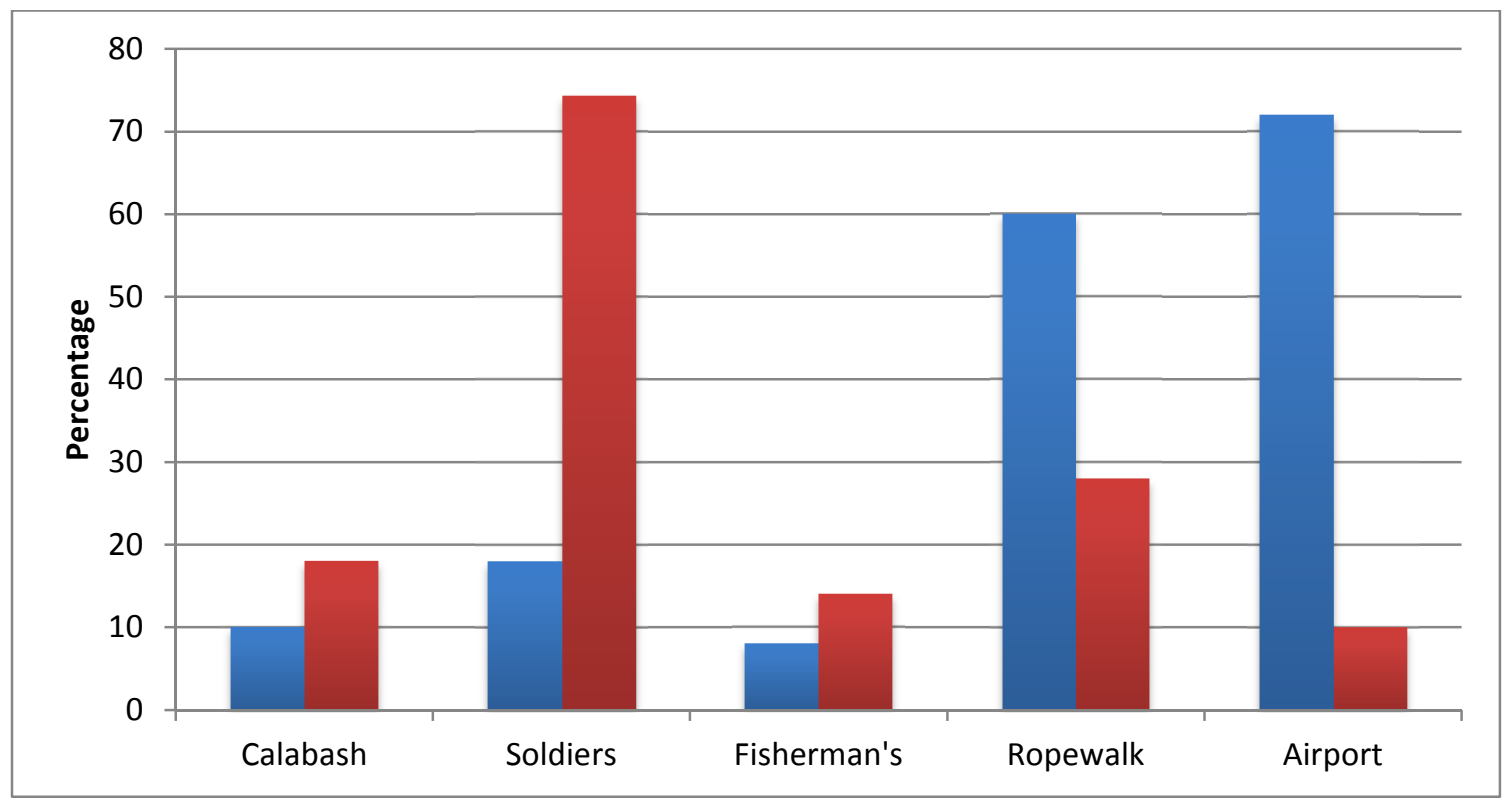

Figure 3.5. Figure showing percent mortality by sites, (blue) intact, (red) cleared. Airport and Ropewalk experienced anthropological disturbances after 2 years. 
Intact vs Cleared: Growth Parameters

Site vs Local

Seedling growth (height) over the 2 year study period differed between mangrove and cleared areas ANOVA: F $(1,341)=24.77, \mathrm{p}<.001$ (Figure 3.6). Average seedling growth (height) was greater in intact $(\mathrm{M}=15.6 \mathrm{~cm})$ than cleared $(\mathrm{M}=10.24 \mathrm{~cm})$ mangroves. A significant difference in mangrove growth (height) was also found among sites, ANOVA: $F(4,341)=88.99, p<.001$. The effect of mangrove clearing varied across sites $($ ANOVA: F $(4,341)=4.03, \mathrm{p}<.003)$. Seedling growth (height) differed between sites except Ropewalk-Airport (Tukey HDS test) (Table 3.3).

Table 3.3: Tukey HDS results for growth (height) according to site, reading from $y$ axis to $x$ axis for mean height between sites. Red highlighted is the detrital mud sediment site (Fisherman's).

\begin{tabular}{|c|c|c|c|c|c|}
\hline Ropewalk & & $>$ & $=$ & $<$ & $<$ \\
\hline Calabash & $<$ & & $<$ & $<$ & $<$ \\
\hline Airport & $>$ & $>$ & & $<$ & $<$ \\
\hline Fisherman's & $>$ & $>$ & $>$ & & $>$ \\
\hline Soldiers & $>$ & $>$ & $>$ & $<$ & \\
\hline & Ropewalk & Calabash & Airport & Fisherman's & Soldiers \\
\hline
\end{tabular}

Seedling growth (height) rates in the cleared area at Fisherman's $(M=27.6 \mathrm{~cm})$ outperformed seedling growth in the intact mangroves $(\mathrm{M}=10.3 \mathrm{~cm})$ at all other site (Figure 3.6). 


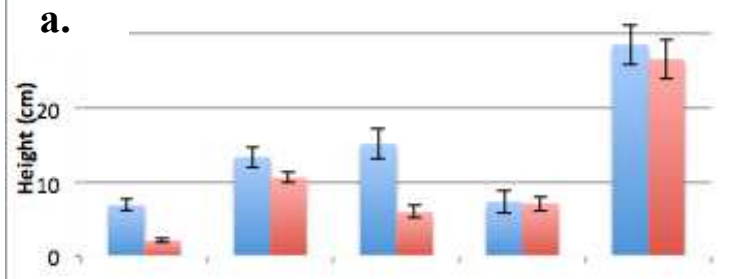

b.
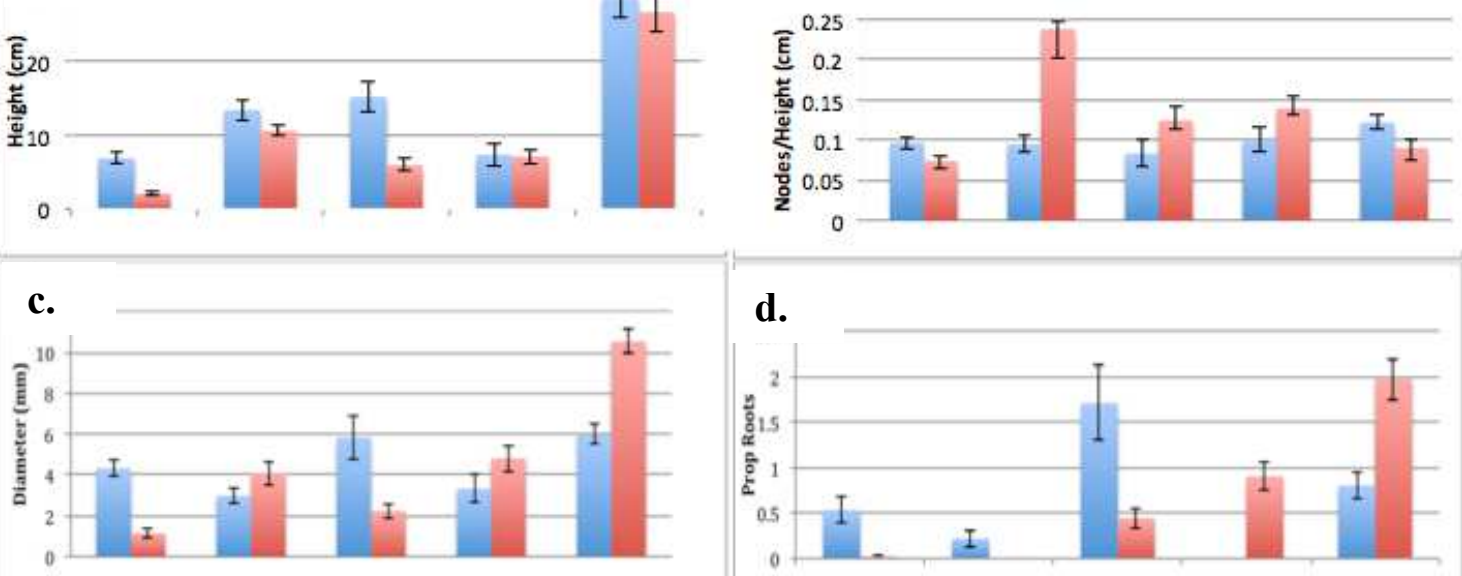

d.
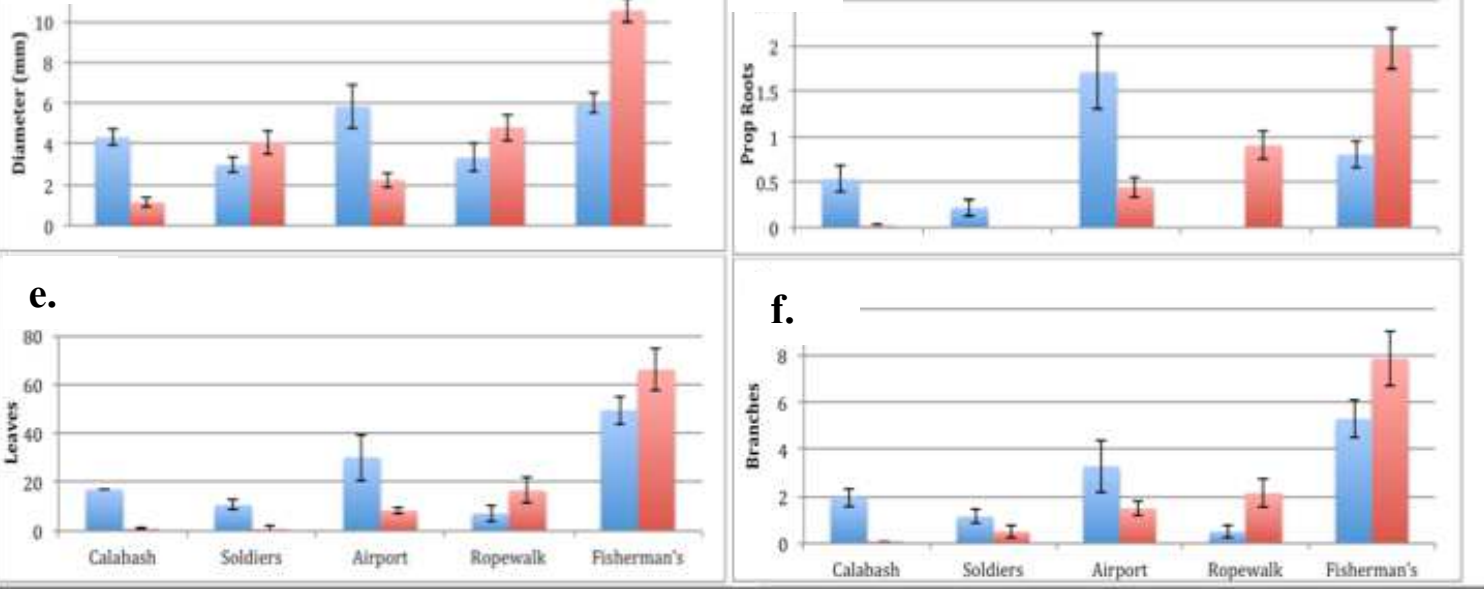

Figure 3.6. Differences in growth parameters: (a) height (cm), (b) nodes (nodes/height), (c) diameter $(\mathrm{mm})$, (d) prop roots, (e) leaves, and (f) branches between intact (blue) and cleared (red) mangroves over two years.

Seedling diameter $(\mathrm{M}=4.5 \mathrm{~mm})$ and node $(\mathrm{M}=0.10$ node $/ \mathrm{cm})$ in intact mangroves are similar to those in cleared seedling diameter $(\mathrm{M}=4.4 \mathrm{~mm})$ and node $(\mathrm{M}=0.11$ node $/ \mathrm{cm}$ ) (Kruskal-Wallis Test results, Table 3.4). However, numbers of leaves, prop roots, and branches differed between seedlings in the cleared and intact areas (Figure 3.6 and Table 3.4). 
Table 3.4: Difference in growth parameters between intact and cleared mangrove seedlings over two year study ( $M=$ intact mangrove, $C=$ cleared mangrove).

\begin{tabular}{|l|c|c|c|c|}
\hline Growth & Mean & Test & Pr & p-value \\
\hline Height $(\mathrm{cm})$ & $\begin{array}{c}15.64(\mathrm{M}) \\
9.41(\mathrm{C})\end{array}$ & ANOVA & $24.77(\mathrm{f})$ & $<.001$ \\
\hline Diameter $(\mathrm{mm})$ & $\begin{array}{c}4.53(\mathrm{M}) \\
4.36(\mathrm{C})\end{array}$ & $\begin{array}{c}\text { Kruskall- } \\
\text { Wallis }\end{array}$ & $3.67\left(\mathrm{x}^{2}\right)$ & .055 \\
\hline Nodes $($ node/cm) & $\begin{array}{c}0.10(\mathrm{M}) \\
0.11(\mathrm{C})\end{array}$ & $\begin{array}{c}\text { Kruskall- } \\
\text { Wallis }\end{array}$ & $0.943\left(\mathrm{x}^{2}\right)$ & .32 \\
\hline Leaves & $25.25(\mathrm{M})$ & Quasi-poisson & $2.00(\mathrm{t})$ & $<.05$ \\
\hline Prop Roots & $18.32(\mathrm{C})$ & GLM & & \\
\hline Branches & $0.59(\mathrm{M})$ & Quasi-poisson & $3.95(\mathrm{t})$ & $<.001$ \\
& $0.72(\mathrm{C})$ & GLM & & \\
\hline
\end{tabular}

\section{Sediment Type}

Seedling growth (height) in the cleared areas over the 2 year study period differed across sediment types ANOVA: F $(2,188)=110.37, \mathrm{p}<.001$ (Figure 3.7). Average seedling growth (height) was greater in the detrital muddy sediment $(\mathrm{M}=26.6 \mathrm{~cm})$ than coral rubble $(\mathrm{M}=10.6 \mathrm{~cm})$ and sandy $(\mathrm{M}=5.0 \mathrm{~cm})$. A significant difference in mangrove growth (height) was also found across sites (ANOVA: F $(2,188)=13.86$, $\mathrm{p}<.001)$. Diameter, nodes, leaves, prop roots, and branches in the cleared areas differed from the intact seedlings (Table 3.5 and Figure 3.7). 
Table 3.5: Differences in growth parameters of cleared area seedlings by sediment type and results from analysis over two year study $(R=$ coral rubble, $S=$ sandy, $D M=$ detrital mud).

\begin{tabular}{|l|c|c|c|c|}
\hline $\begin{array}{l}\text { Growth } \\
\text { Parameters }\end{array}$ & Mean & Test & Pr & p-value \\
\hline Height $(\mathrm{cm})$ & $10.58(\mathrm{R})$ & ANOVA & $110.37(\mathrm{f})$ & $<.001$ \\
& $\begin{array}{l}4.96(\mathrm{~S}) \\
26.59(\mathrm{DM})\end{array}$ & & & \\
& $4.1(\mathrm{R})$ & Kruskall- & $80.24\left(\mathrm{x}^{2}\right)$ & $<.001$ \\
& $2.6(\mathrm{~S})$ & Wallis & & \\
& $10.56(\mathrm{DM})$ & & & \\
\hline Diameter $(\mathrm{mm})$ & $0.24(\mathrm{R})$ & Kruskall- & $19.98\left(\mathrm{x}^{2}\right)$ & $<.001$ \\
& $0.11(\mathrm{~S})$ & Wallis & & \\
& $0.09(\mathrm{DM})$ & & & $<.05$ \\
& $0.785(\mathrm{R})$ & Quasi-Poisson & $2.00(\mathrm{t})$ & \\
\hline Leaves & $8.32(\mathrm{~S})$ & GLM & & $<.001$ \\
& $66.07(\mathrm{DM})$ & & & \\
\hline Prop Roots & $0(\mathrm{R})$ & Quasi-Poisson & $3.95(\mathrm{t})$ & $<$ \\
& $0.44(\mathrm{~S})$ & GLM & & \\
& $1.98(\mathrm{DM})$ & & & \\
\hline Branches & $0.5(\mathrm{R})$ & Quasi-Poisson & $2.00(\mathrm{t})$ & $<.05$ \\
& $1.19(\mathrm{~S})$ & GLM & & \\
& $7.86(\mathrm{DM})$ & & & \\
\hline
\end{tabular}




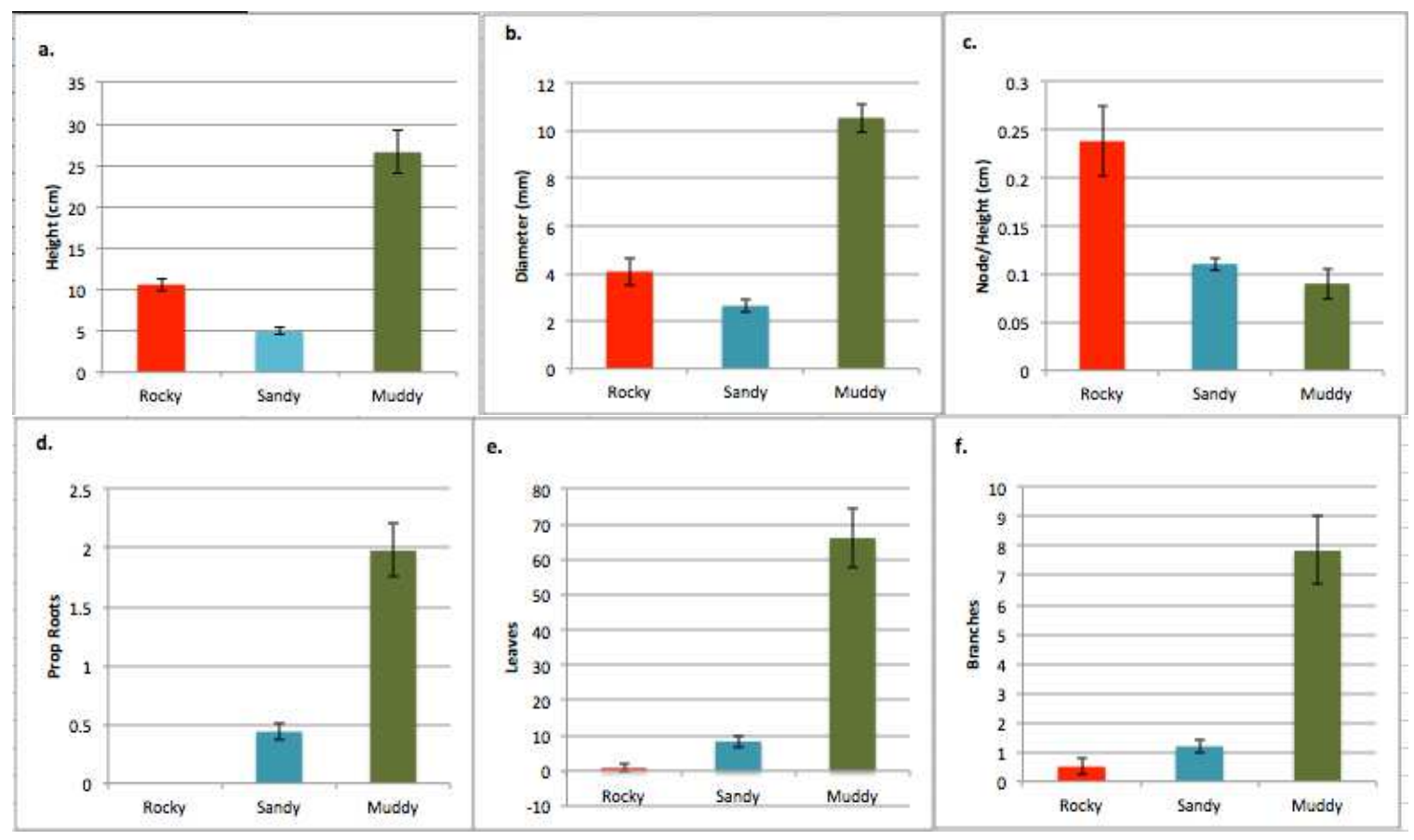

Figure 3.7. Differences in growth parameters by sediment type in cleared areas: (a) height $(\mathrm{cm})$, (b) diameter $(\mathrm{mm})$, (c) nodes by height $(\mathrm{d})$ prop roots $(\mathrm{cm})$, (e) leaves, and (f) branches (muddy = detrital mud).

Treatments: Seedling Growth Experiment

Control vs Nutrient-Control

Equal mortality was experienced across the treatment types. Change in height over the two years was similar between the nutrient control seedlings $(\mathrm{N}=16), \mathrm{M}=9.9 \mathrm{~cm}$ $(\mathrm{SD}=1.12)$ and the control seedlings $(\mathrm{N}=16) \mathrm{M}=15.34 \mathrm{~cm}(\mathrm{SD}=1.33)$ (independent samples t-test: $\mathrm{t}(30)=0.61, \mathrm{p}=0.547)$. Thus, burial of plaster of paris blocks did not affect seedling growth. 
Treatments vs Sediment

Growth (height) differed by sediment type; ANOVA: $F(1,61)=75.88, p<.001$ and by sediment*treatment, ANOVA: $\mathrm{F}(3,61)=2.84, \mathrm{p}<.05$ (Table 3.6 and Figure 3.8). Across all treatments the average height was greater in the detrital mud sediment $(\mathrm{M}=$ $32.8 \mathrm{~cm})$ than the sandy sediment $(\mathrm{M}=9.4 \mathrm{~cm})$; seedling growth differed between sediment types for all treatments except nutrient/wave (Tukey HDS test) (Table 3.7).

Table 3.6: Differences in growth parameters ANOVA results of cleared area seedlings by sediment type and treatments.

\begin{tabular}{|l|c|c|c|c|}
\hline Source & $\begin{array}{c}\text { Sum of } \\
\text { Squares }\end{array}$ & df & F & \multicolumn{1}{l|}{ p-value } \\
\hline Height & 8070 & 1 & 75.88 & $<.001$ \\
\hline Sediment & 171 & 3 & 0.54 & 0.66 \\
\hline Treatment & 905 & 3 & 2.84 & $<.05$ \\
\hline Sediment*Treatment & 778.8 & 1 & 46.16 & $<.001$ \\
\hline Diameter & 62.1 & 3 & 1.228 & 0.31 \\
\hline Sediment & 175.9 & 3 & 3.48 & $<.05$ \\
\hline Treatment & & & & \\
\hline Sediment*Treatment & 0.04 & 1 & 4.45 & $<.05$ \\
\hline Nodes & 0.01 & 3 & 0.43 & 0.73 \\
\hline Sediment & 0.005 & 3 & 0.20 & 0.90 \\
\hline Treatment
\end{tabular}




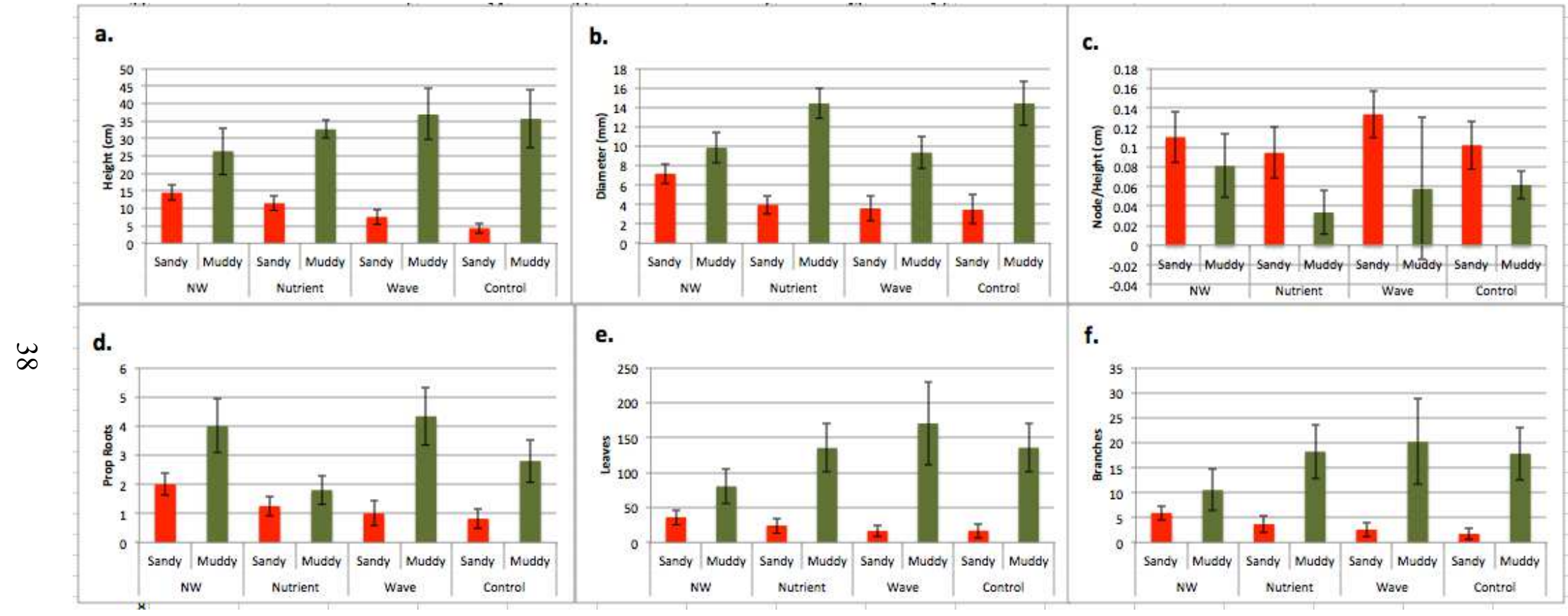

Figure 3.8. Growth responses by treatment and sediment type: (a) height $(\mathrm{cm}),(b)$ diameter $(\mathrm{mm})$, (c) nodes (number of nodes/height of seedling), (d) leaves $(\mathrm{cm})$, (e) prop roots, and (f) branches over two years (muddy $=$ detrital mud). 
Table 3.7: Differences in growth parameters Tukey HDS test results of cleared area seedlings by sediment type and treatments.

\begin{tabular}{|c|c|c|c|}
\hline Source & Mean $(\mathrm{cm})$ & SD & p-value \\
\hline \multicolumn{4}{|l|}{ Height } \\
\hline \multicolumn{4}{|l|}{ Control } \\
\hline Sandy & 4.27 & 5.00 & \multirow[t]{2}{*}{$<.001$} \\
\hline Detrital Mud & 35.6 & 18.64 & \\
\hline \multicolumn{4}{|c|}{ Nutrient/Wave } \\
\hline Sandy & 14.4 & 7.57 & \multirow[t]{2}{*}{0.31} \\
\hline Detrital Mud & 26.33 & 16.45 & \\
\hline \multicolumn{4}{|l|}{ Nutrient } \\
\hline Sandy & 11.42 & 7.04 & \multirow[t]{2}{*}{$<.05$} \\
\hline Detrital Mud & 32.6 & 5.68 & \\
\hline \multicolumn{4}{|l|}{ Wave } \\
\hline Sandy & 7.5 & 7.34 & \multirow[t]{2}{*}{$<.001$} \\
\hline Detrital Mud & 36.83 & 17.87 & \\
\hline \multicolumn{4}{|l|}{ Diameter } \\
\hline \multicolumn{4}{|l|}{ Control } \\
\hline Sandy & 3.45 & 4.95 & \multirow[t]{2}{*}{$<.001$} \\
\hline Detrital Mud & 14.4 & 5.03 & \\
\hline \multicolumn{4}{|c|}{ Nutrient/Wave } \\
\hline Sandy & 7.17 & 3.61 & \multirow[t]{2}{*}{0.89} \\
\hline Detrital Mud & 9.83 & 3.92 & \\
\hline \multicolumn{4}{|l|}{ Nutrient } \\
\hline Sandy & 3.96 & 3.35 & \multirow[t]{2}{*}{$<.001$} \\
\hline Detrital Mud & 14.4 & 3.4 & \\
\hline \multicolumn{4}{|l|}{ Wave } \\
\hline Sandy & 3.58 & 4.40 & \multirow[t]{2}{*}{0.11} \\
\hline Detrital Mud & 9.33 & 4.00 & \\
\hline
\end{tabular}


Across all treatments the average diameter was greater in the detrital mud sediment $(\mathrm{M}=11.9 \mathrm{~mm})$ than the sandy sediment $(\mathrm{M}=4.5 \mathrm{~mm})($ ANOVA: $\mathrm{F}(1,61)=$ 46.16, $\mathrm{p}<.001$ ) and by sediment*treatment (ANOVA: $\mathrm{F}(3,61)=3.48, \mathrm{p}<.05)$ (Table 3.6). Seedling growth differed between sediment types for control seedlings and nutrient seedlings (Tukey HDS test) (Table 3.7).

Average nodes per height was greater in the sandy sediment $(\mathrm{M}=0.12$ node $/ \mathrm{cm})$ than detrital mud $(\mathrm{M}=0.06$ node $/ \mathrm{cm})($ ANOVA: $\mathrm{F}(1,60)=4.45, \mathrm{p}<.05)$ (Table 3.6). Across all treatments the average leaves, prop roots and branches were greater in the detrital mud sediment $(\mathrm{M}=129.9$ leaves $)(\mathrm{M}=3.32$ prop roots $)(\mathrm{M}=16.6$ branches $)$ than the sandy sediment $(\mathrm{M}=23.6$ leaves $)(\mathrm{M}=1.27$ prop roots $)(\mathrm{M}=3.5$ branches $)$ (Table 3.8 and Figure 3.8). 
Table 3.8: Differences in growth parameters Quasi Poisson GLM results and means of cleared area seedlings by sediment type and treatments over two year study

\begin{tabular}{|l|c|c|c|}
\hline Treatment & Leaves & Prop Roots & Branches \\
\hline P-value & $<.001$ & $<.05$ & $<.001$ \\
\hline t- value & $\mathbf{1 6 . 8 4}$ & $\mathbf{3 . 3 1}$ & $\mathbf{8 . 7 5}$ \\
\hline Control & 16.91 & 0.82 & 1.73 \\
\hline Sandy & 135.60 & 2.8 & 17.8 \\
\hline Detrital Mud & \multicolumn{1}{|l|}{} \\
\hline Nutrient/Wave & 36.08 & 2.0 & 5.9 \\
\hline Sandy & 80.33 & 4.0 & 10.50 \\
\hline Detrital Mud & & & \\
\hline Nutrient & 24.25 & 1.25 & 3.67 \\
\hline Sandy & 135.20 & 1.8 & 18.2 \\
\hline Detrital Mud & 16.58 & 1.0 & 2.58 \\
\hline Wave & 170.33 & 4.33 & 20.17 \\
\hline Sandy
\end{tabular}

\section{Treatment vs Site}

Seedling growth (height) in the cleared areas over the 2 year period differed by site $($ ANOVA: $\mathrm{F}(2,57)=38.82, \mathrm{p}<.001)$ (Figure 3.9 and Table 3.9), except for nutrient/wave treatments and among sites with similar sediment (Tukey HDS test) (Table 3.10). Average seedling growth (height) was: greater with both nutrient/wave $(\mathrm{M}=18.4$ $\mathrm{cm})$ and nutrient $(\mathrm{M}=17.65 \mathrm{~cm})$ treatments compared to controls $(\mathrm{M}=10.8 \mathrm{~cm})$ across all sites. 

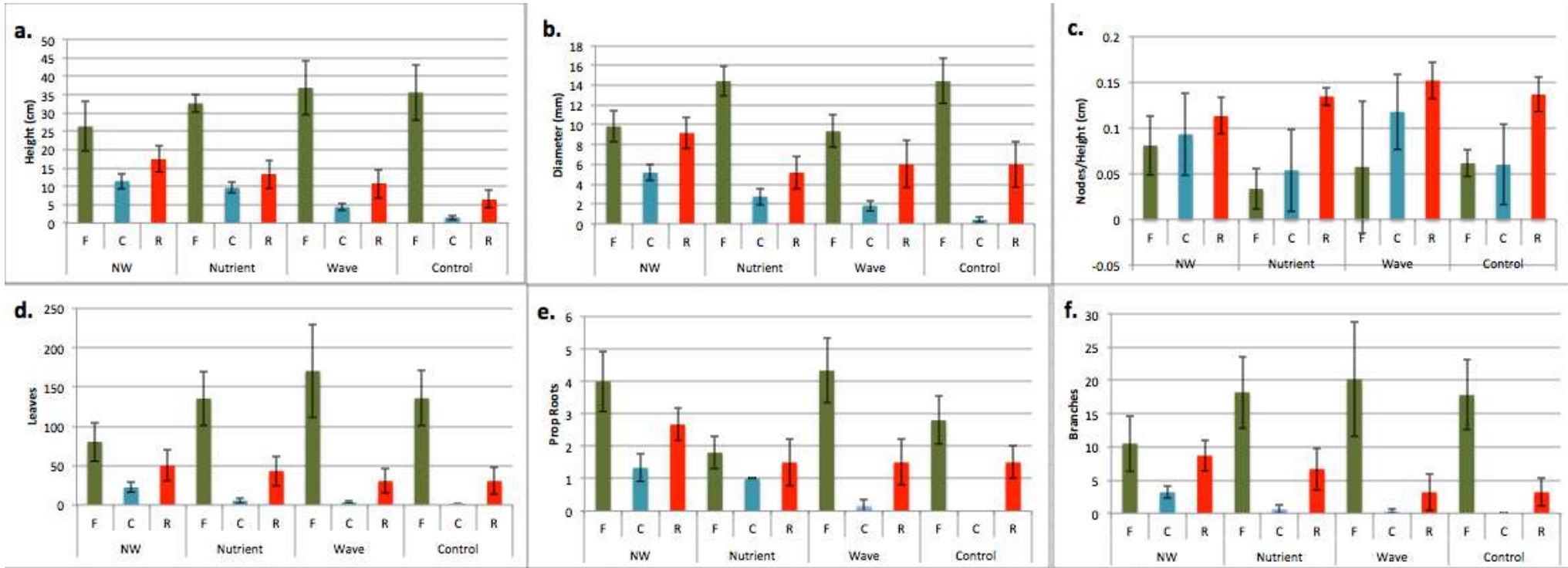

Figure 3.9. Differences in growth responses to treatments in cleared areas: (a) height (cm), (b) diameter (mm), (c) nodes by height, (d) leaves $(\mathrm{cm})$, (e) prop roots, and (f) branches between sites $\mathrm{F}=\mathrm{Fisherman}$ 's, $\mathrm{C}=\mathrm{Calabash}$, $R=$ Ropewalk) over two years. 
Table 3.9: ANOVA growth results for treatments*site.

\begin{tabular}{|c|c|c|c|c|}
\hline Source & $\begin{array}{c}\text { Sum of } \\
\text { Squares } \\
\end{array}$ & df & $\mathbf{F}$ & p-value \\
\hline \multicolumn{5}{|l|}{ Height } \\
\hline Site & 8371 & 2 & 38.82 & $<.001$ \\
\hline Treatment & 185 & 3 & 0.57 & 0.63 \\
\hline Site*Treatment & 935 & 6 & 1.44 & 0.22 \\
\hline \multicolumn{5}{|l|}{ Diameter } \\
\hline Site & 947 & 2 & 32.09 & $<.001$ \\
\hline Treatment & 62 & 3 & 1.40 & 0.25 \\
\hline Site*Treatment & 195 & 6 & 2.21 & 0.05 \\
\hline \multicolumn{5}{|l|}{ Node } \\
\hline Site & 0.06 & 2 & 3.82 & $<.05$ \\
\hline Treatment & 0.01 & 3 & 0.48 & 0.7 \\
\hline Site*Treatment & 0.02 & 6 & 0.34 & 0.9 \\
\hline
\end{tabular}


Table 3.10: Tukey HSD test growth (height) analysis of treatment*site pairs vs sites following a two-way ANOVA.

\begin{tabular}{|c|c|c|c|c|c|}
\hline Source & \multicolumn{2}{|c|}{ Mean (cm) } & \multicolumn{2}{|c|}{ SD } & p-value \\
\hline \multicolumn{6}{|l|}{ Control } \\
\hline Fisherman's vs Calabash & 35.6 & 1.5 & 9.6 & 1.4 & $<.001$ \\
\hline Fisherman's vs Ropewalk & & 6.6 & & 5.8 & $<.001$ \\
\hline Ropewalk vs Calabash & & & & & 0.99 \\
\hline \multicolumn{6}{|l|}{ Nutrient/Wave } \\
\hline Fisherman's vs Calabash & 26.3 & 11.4 & 16.5 & 5.1 & 0.37 \\
\hline Fisherman's vs Ropewalk & & 17.5 & & 8.8 & 0.94 \\
\hline Ropewalk vs Calabash & & & & & 0.99 \\
\hline \multicolumn{6}{|l|}{ Nutrient } \\
\hline Fisherman's vs Calabash & 32.6 & 9.6 & 5.7 & 3.6 & $<.05$ \\
\hline Fisherman's vs Ropewalk & & 13.2 & & 9.4 & $<.05$ \\
\hline Ropewalk vs Calabash & & & & & 0.99 \\
\hline \multicolumn{6}{|l|}{ Wave } \\
\hline Fisherman's vs Calabash & 36.8 & 4.3 & 17.8 & 2.3 & $<.001$ \\
\hline Fisherman's vs Ropewalk & & 10.6 & & 9.4 & $<.05$ \\
\hline Ropewalk vs Calabash & & & & & 0.99 \\
\hline
\end{tabular}

Seedling diameter in the cleared areas over the 2 year period differed by site, $($ ANOVA: $F(2,57)=32.09, p<.001)$ and by site*treatment $(\operatorname{ANOVA}: F(6,57)=2.21$, $\mathrm{p}=.05$ ) (Table 3.9), except for nutrient/wave treatments and across sites with similar sediment type (Tukey HDS test) (Table 3.11). 
Table 3.11: Tukey HSD test diameter analysis of treatment*site pairs vs sites following a two-way ANOVA.

\begin{tabular}{|l|c|c|c|c|c|c|}
\hline Source & Mean (mm) & \multicolumn{2}{l|}{ SD } & p-value \\
\hline Control & 14.4 & 0.4 & 5.0 & 0.5 & $<.001$ \\
\hline Fisherman's vs Calabash & & 6.0 & & 5.6 & $<.05$ \\
\hline Fisherman's vs Ropewalk & & & & & 0.42 \\
\hline Ropewalk vs Calabash & 9.8 & 5.1 & 3.9 & 1.9 & 0.62 \\
\hline Nutrient/Wave & & 3.9 & & 3.9 & 0.99 \\
\hline Fisherman's vs Calabash & & & & & 0.81 \\
\hline Fisherman's vs Ropewalk & & & & \\
\hline Ropewalk vs Calabash & 14.4 & 2.8 & 3.4 & 2.0 & $<.001$ \\
\hline Nutrient & & 5.2 & & 4.1 & $<\mathbf{0 . 0 1}$ \\
\hline Fisherman's vs Calabash & & & & & 0.99 \\
\hline Fisherman's vs Ropewalk & & & & & 0.91 \\
\hline Ropewalk vs Calabash & 9.3 & 1.8 & 3.9 & 1.3 & $<.05$ \\
\hline Wave & & 6.0 & & 2.4 & 0.81 \\
\hline Fisherman's vs Calabash & & & \\
\hline Fisherman's vs Ropewalk & & & \\
\hline Ropewalk vs Calabash & & & & \\
\hline
\end{tabular}

Node (nodes per height) differed across sites (ANOVA: F $(2,56)=3.82, \mathrm{p}<.05)$ (Table 3.9).

\section{Nutrient/Wave and Nutrient vs Intact Mangrove}

Seedlings with nutrient/wave treatments had similar growth (height) to intact mangroves within sites. Seedling nutrient treatments also had similar growth (height) to 
intact mangroves within sites (Table 3.4). Average seedling growth (height) was: intact mangroves $(\mathrm{M}=15.6 \mathrm{~cm}), \mathrm{NW}(\mathrm{M}=18.4 \mathrm{~cm}), \mathrm{N}(\mathrm{M}=17.7 \mathrm{~cm})$ (Table 3.12). However mangrove growth (height) rates differed among sites.

Table 3.12: Height growth ANOVA results of cleared area Nutrient/Wave and Nutrient compared to intact Mangroves.

\begin{tabular}{|l|c|c|c|c|}
\hline Source & $\begin{array}{c}\text { Sum of } \\
\text { Squares }\end{array}$ & df & F & p-value \\
\hline Nutrient/Wave vs Intact & 25.42 & 2 & 9.90 & $<.001$ \\
\hline Site & 0.62 & 1 & 0.48 & .496 \\
\hline Treatment & 5.78 & 2 & 2.25 & .130 \\
\hline Site*Treatment & \multicolumn{5}{|l|}{} \\
\hline Nutrient vs Intact & 2 & 22.91 & $<.001$ \\
\hline Site & 0.35 & 1 & 0.30 & .549 \\
\hline Treatment & 0.60 & 2 & 0.32 & .732 \\
\hline Site*Treatment & & & & \\
\hline
\end{tabular}

\section{DISCUSSION}

Seedlings in intact mangrove areas had lower mortality and more rapid growth than seedlings in cleared mangrove areas. Seedlings at sites with detrital mud substrate outperformed seedlings at coral rubble and sandy substrate sites across all growth parameters. When treatments were applied to test factors limiting seedlings growth, the seedlings at detrital mud sites outperformed seedlings at sand sites for all treatments (nutrient, nutrient/wave, wave, control) except nutrient/wave. Seedlings receiving nutrient or nutrient/wave treatments in the cleared areas performed comparable to seedlings growing in the intact mangroves within the same site. Feller et al. (2007) at 
Twin Cays, Belize was able to bring $A$. germinans out of a stunted form by alleviating Pnutrient deficiency. Photos from the study show growth structure differences after nutrients were added to the seedlings (Figure 3.9 and 3.10). In this study, addition of nutrients or nutrients and wave barriers (nutrient/wave, $\mathrm{M}=18.41 \mathrm{~cm}$; nutrient, $\mathrm{M}=$ $17.65 \mathrm{~cm})$ increased growth outputs comparable to or better than intact mangroves $(\mathrm{M}=$ $15.6 \mathrm{~cm})$. 

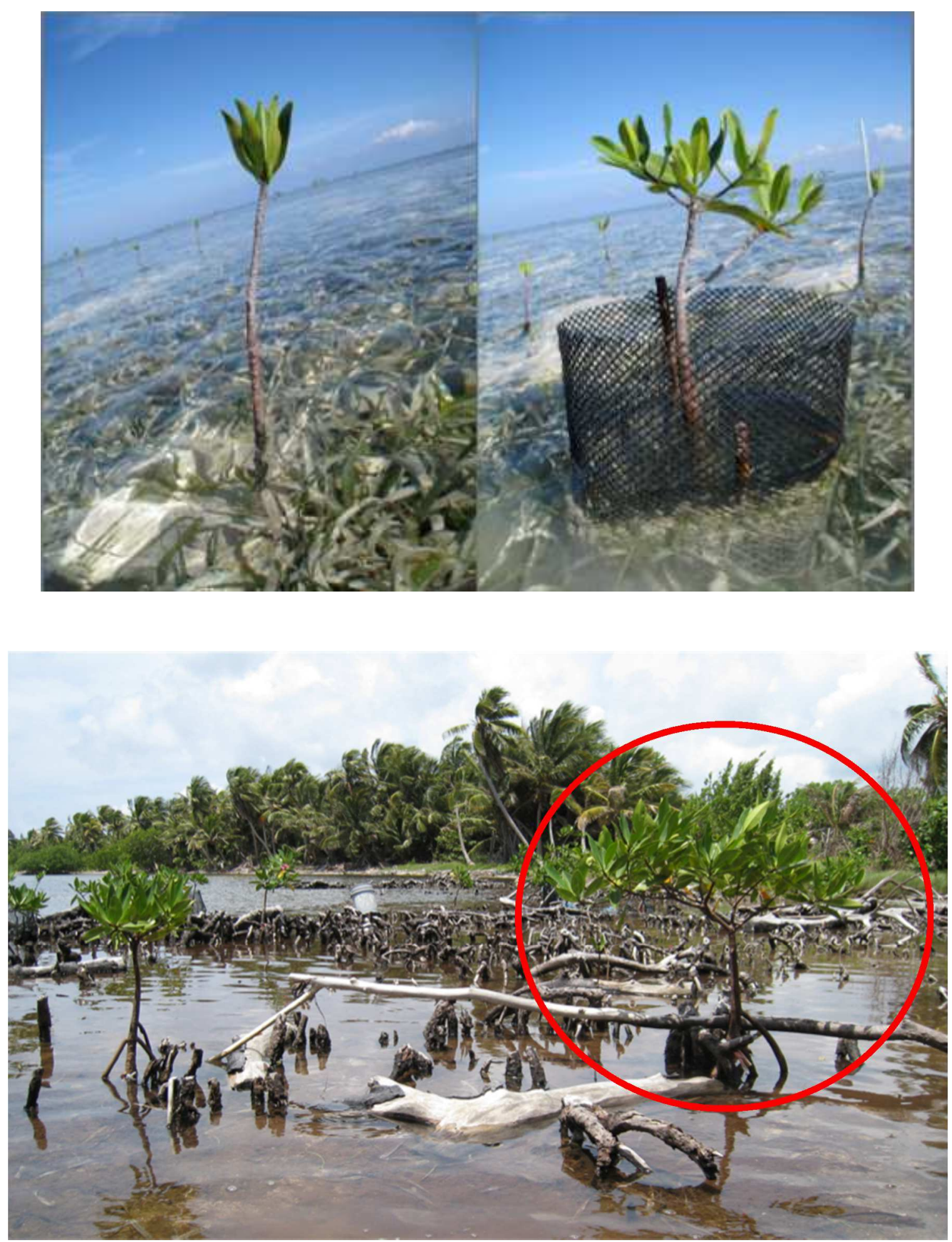

Figure 3.10. Photo of a control seedling (top left) and a nutrient wave seedling (top right) at Calabash cleared site and nutrient addition seedling (circled in bottom photo) at Fisherman's cleared site . 


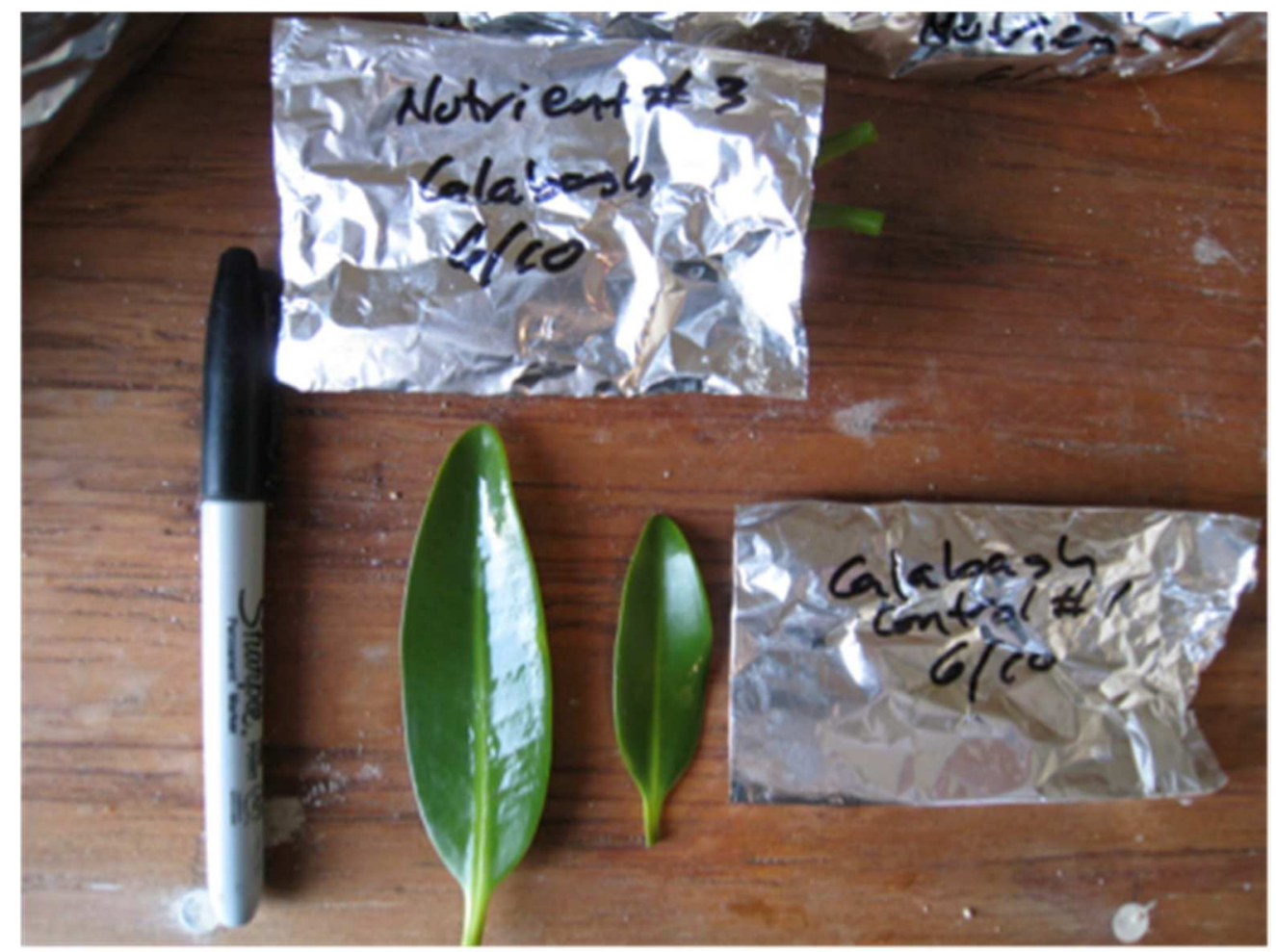

Figure 3.11. Photo comparing leaf size, control (right) and nutrient (left) from Calabash.

The dredging at Ropewalk increased sediment suspension for four months during the summer of 2009; it is hypothesized that the increased suspension of sand during the dredging process smothered the intact mangrove seedlings resulting in the higher than expected mortality rate in Ropewalk's intact area. Soldiers', the coral rubble site with very little organic matter or sand that was clearing $~ 50 y$ rs prior, experienced a very high mortality rate in the cleared area (74\%) compared to the other sites.

Though seedlings in intact mangrove areas had higher growth rates than seedlings in the cleared areas at Calabash, Soldiers and Airport, this was not the case at 
Fisherman's and Ropewalk. Fisherman's, a site that had been recently cleared $(\sim 2$ yrs prior to study), had a thick dark layer of organic matter remaining in the cleared area. The intact area at Fisherman's was a dense mangrove forest with crowding and light limitation. Cleared area seedlings at Fisherman's had higher growth of prop roots, branches, leaves and diameter in the cleared than the intact area. This pattern is likely because in the cleared area the nutrients are comparable to the intact area, but the lack of adult trees in the cleared area released those seedlings from the competition for space and light that seedlings in the intact mangrove area experience. At Ropewalk, the site was impacted by dredging. The dredging process may have released nutrients into suspension near the cleared area seedlings resulting in higher than expected growth. In the intact areas the sediment was moved significantly around the intact seedlings which may have resulted in increased susceptibility to wave energy.

Sediment type affected seedling growth rates in the cleared areas with detrital mud sites outperformed sandy and coral rubble sites in all growth parameters (Figure 3.6). Even with the addition of nutrients, performance of seedlings at the sandy sites is lower than at the detrital mud site (Figure 3.7), but better than the controls in their respective sediments. Therefore mangrove restoration projects that are able to target habitat with nutrient rich sediment are likely to be more successful. Planting seedlings near established mangrove forests could be an effective strategy to expand/reestablish mangrove forests. If planting in low nutrient sediment is the only option, survival and growth rates will be reduced (Salmo 2013, Dale 2014) unless nutrients are added (Krumholz 2007); growth can be further enhanced with wave protection. 
With restoration projects becoming prevalent throughout the world to remedy mangrove degradation and extensive losses, focus on approaches that will improve project success is important (Dale 2014, Lewis 2005). While appropriate hydrological and geomorphological conditions are important for mangrove survival, this study confirms the importance of nutrients and wave protection on the survival and growth of mangrove seedlings during such projects.

Though replanted mangrove forests can approach the biomass, stand structure, and productivity of undisturbed forests within 20-25 years (McKee \& Faulkner 2000), managers face problems of low initial survival rate and poor growth and fitness during the first few years (Kairo 2001; Lewis 2005). Often mangrove restoration projects plant seedlings without first identifying and mitigating the stressors limiting natural regeneration; this can result in low survival rates and poor fitness (Lewis 2005). High mortality rates also result when project managers fail to accommodate mangroves' biological requirements and place seedlings in mudflats, sandflats, or seagrass, which are stressful environments for the trees. Some of these areas have inadequate nutrients, strong winds and/or waves that damage the seedlings (Lewis 2002, Walters 2000).

The experiment presented here indicates that the higher growth outputs at Fisherman's compared to other sites are likely due to the presence of remaining mangrove detritus that had not yet been washed out of the recently cleared sites. This finding suggests that after mangrove removal, if seedlings are replanted where nutrients have been retained at the site, seedlings may have increased growth outputs and lower mortality. For example, following a mangrove clearing for timber, if managers planned 
replanting before the organic detrital mud is eroded, this study suggests that mortality rates would decrease and growth parameters would increase. Since seedlings receiving nutrient or nutrient/wave treatments in the cleared areas performed comparable to seedlings growing in the intact mangroves, restoration projects at sites with suboptimal conditions (poor nutrient quality substrate) could attain higher survival and growth outputs with nutrient addition.

In future mangrove restoration, project design that considers biogeophysical variables can ensure successful establishment of mangroves at minimal cost. Only where natural recovery of seedlings is not occurring or is unsuccessful should assistance through planting or enriching seedlings be considered (Lewis 2005). For example, restoring hydrologic connections to impounded mangrove areas in Florida (Brockmeyer et al. 1997), Costa Rica and Philippines (Stevenson et al. 1999) using basic principles of ecological mangrove restoration (Lewis 2010) have been necessary in some cases.

It is estimated that there are over 250,000 ha of abandoned shrimp ponds worldwide in mangrove forest zones (Stevenson 1997). These abandoned shrimp ponds are in the intertidal zone, which in many cases originally mangrove habitat, and often have high levels of sediment nutrients due to the aquaculture practices. Decommissioning these abandoned shrimp ponds and "filling-in" forest openings may provide the nutrients lacking in some locations and possibly result in higher success rates for the survival of seedlings (Stevenson et al. 1999).

Lack of baseline information for proposed restoration areas can lead to selecting sites with unsuitable soil, extensive erosion, or areas with unsuitable wave energy (Kairo 2001 and Lewis 2002). Working with natural recovery processes by expanding 
mangrove ecosystems from existing mangroves (planting seedlings close to established trees) where possible or enhancing conditions to meet the ecological needs of settling seedlings may remedy the limiting factors of insufficient nutrients and excessive wave energy. Consideration of the factors limiting survival and growth outputs identified in this study has the potential to increase success of future mangrove restoration projects. 


\section{CHAPTER 4: CONCLUSION}

Chapter 2 finds that removal of mangrove vegetation stops soil accretion, though decomposition, physical compaction and erosion processes continue, eventually leading to increased submergence and land loss. This land loss is exacerbated where fringing reef is not continuous. These data highlight the need for careful consideration of the subtidal features adjacent to sites slated for mangrove removal or transformation. Such information may prove useful in identifying areas that are most vulnerable to erosion following mangrove removal, a potential tool for determining where mangrove clearing is most likely to impact coastal protection.

Given these impacts of mangrove clearing, it is important to identify successful approaches for mangrove restoration. The study presented in Chapter 3 found that seedlings in intact mangrove areas had lower mortality and more rapid growth than seedlings in cleared mangrove areas, particularly the cleared sites with coral rubble or sand with seagrass substrate. The detrital mud sites outperformed rubble and sandy sites in seedling growth parameters.

The experiment examined factors limiting seedlings in cleared areas. Seedlings growth at sites with detrital mud exceeded growth at sites with sand substrate regardless of treatments (nutrient, nutrient/wave, wave, control) except nutrient/wave. Seedlings receiving nutrient or nutrient/wave treatments performed comparable to seedlings growing in the intact mangroves. Therefore, mangrove restoration projects that have suboptimal conditions for restoration (e.g. poor nutrient quality substrate) could attain similar seedling growth rates as intact areas with nutrient addition. 
Survival and growth outputs desired for successful restoration will depend on the nutrient levels and location of new seedlings. Planting seedlings near established mangrove forests could be an effective strategy to expand/reestablish mangrove forests. If planting seedlings close to established mangrove forests is infeasible, it may be necessary to apply nutrient addition and/or wave barriers to increase growth outputs and survival rates. Results of this study can be used to address the impacts of coastal development and mangrove clearing, which could lead to better management and restoration plans for tropical coastal ecosystem. 


\section{LITERATURE CITED}

Alongi DM (2002) Present state and future of the world's mangrove forests.

Environmental Conservation 29.03: 331-349

Arens SM, Slings Q, De Vries CN (2004) Mobility of a remobilised parabolic dune in Kennemerland, The Netherlands. Geomorphology 59(1):175-188

Augustinus PGEF (1995) Chapter 12 Geomorphology and Sedimentology of Mangroves. In: Perillo GME (ed) Developments in Sedimentology, Book Volume 53. Elsevier

Bird ECF (1986) Mangroves and intertidal morphology in Westernport Bay, Victoria, Australia. Marine Geology 69:251-271

Bird ECF, Barson MM (1977) Measurement of physiographic changes on mangrovefringed estuaries and coastlines. Marine Research in Indonesia, 18:73-80

Blasco F, Saenger P, Janodet E (1996) Mangroves as indicators of coastal change. CATENA 27:167-178

Bosire JO, Dahdouh-Guebas F, Walton M, Crona BI, Lewis III RR, Field C, ... Koedam N (2008) Functionality of restored mangroves: a review. Aquatic Botany, 89(2): 251-259

Bouillon S, Borges AV, Castañeda $\square$ Moya E, Diele K, Dittmar T, Duke NC, ... Twilley RR (2008) Mangrove production and carbon sinks: a revision of global budget estimates. Global Biogeochemical Cycles, 22(2)

Brockmeyer Jr RE, Rey JR, Virnstein RW, Gilmore RG, Ernest L, (1997) Rehabilitation of impounded estuarine wetlands by hydrologic reconnection to the Indian River Lagoon, Florida (USA). Wetland Ecology Management 4 (2): 93-109

Cahoon DR, Hensel P, Rybczyk J, McKee KL, Proffitt CE, Perez BC (2003) Mass tree mortality leads to mangrove peat collapse at Bay Islands, Honduras after Hurricane Mitch. Journal of Ecology 91:1093-1105

Chen B, Yu W, Liu W, Liu Z (2012) An assessment on restoration of typical marine ecosystems in china-Achievements and lessons. Ocean \& Coastal Management, 57:53-61

Crooks S, Turner RK (1999) Integrated Coastal Management: Sustaining Estuarine Natural Resources. In: Nedwell D, Raffaelli D (eds) Advances in Ecological Research, Book Volume 29. Academic Press

Dale PER, Knight JM, Dwyer PG (2014) Mangrove rehabilitation: a review focusing on ecological and institutional issues. Wetlands Ecology and Management, 22(6): 587-604

Danielsen F, Sørensen MK, Olwig MF, Selvam V, Parish F, Burgess ND, Hiraishi T, Karunagaran VM, Rasmussen MS, Hansen LB, Quarto A, Suryadiputra, N. (2005). The Asian tsunami: a protective role for coastal vegetation. Science, 310:643

Duke NC, Meynecke J-O, Dittmann S, Ellison AM, Anger K, Berger U, Cannicci S, Diele K, Ewel KC, Field CD, Koedam N, Lee SY, Marchand C, Nordhaus I, Dahdouh-Guebas F (2007) A world without mangroves? Science 317:41-42 
Ellison AM (2000) Mangrove Restoration: Do We Know Enough? Restoration Ecology $8: 219-229$

Elster C (2000) Reasons for reforestation success and failure with three mangrove species in Colombia. Forest Ecology and Management, 131(1): 201-214

FAO (Food and Agriculture Organization of the United Nations) (2003) Status and Trends in Mangrove Area Extent Worldwide. Forest Resources Division, Paris.

FAO (Food and Agriculture Organization of the United Nations) (2007) The world's mangroves 1980-2005. FAO Forestry Paper 153. FAO, Rome

Feller IC, Lovelock CE, McKee KL (2007) Nutrient addition differentially affects ecological processes of Avicennia germinans in nitrogen versus phosphorus limited mangrove ecosystems. Ecosystems 10.3: 347-359

Field CD (1998) Rehabilitation of mangrove ecosystems: an overview. Mar. Pollut. Bull. 37:383-392

Golbuu Y, Victor S, Wolanski E, Richmond RH (2003) Trapping of fine sediment in a semi-enclosed bay, Palau, Micronesia. Estuarine, Coastal and Shelf Science 57:941949

Granek EF, Ruttenberg BI (2007) Protective capacity of mangroves during tropical storms: a case study from 'Wilma' and 'Gamma'. Mar Ecol Prog Ser 343:101-105

Greipsson S, Davy AJ (1996) Sand accretion and salinity as constraints on the establishment of Leymus arenarius for land reclamation in Iceland. Annals of Botany 78: 611-618

Hugenholtz CH, Wolfe SA, Walker IJ, Moorman BJ (2009) Spatial and temporal patterns of aeolian sediment transport on an inland parabolic dune, Bigstick Sand Hills, Saskatchewan, Canada. Geomorphology 105(1):158-170

Kairo JG, Dahdouh-Gueba F, Bosire J, Koedam N. (2001) Restoration and management of mangrove systems- a lesson for and from the East African region. South African Journal of Botany 67.3: 383-389

Kaly UL, Eugelink G, Robertson AI (1997) Soil conditions in damaged North Queensland mangroves. Estuaries 20:291 $\square 300$

Kar R, Kar RK (2005) Mangroves can check the wrath of tsunami. Current Sci (Bangalore) 88:675

Kentula ME (2000) Perspectives on setting success criteria for wetland restoration. Ecological Engineering, 15(3):199-209

Kristensen E, Bouillon S, Dittmar T, Marchand C (2008) Organic carbon dynamics in mangrove ecosystems: a review. Aquatic Botany, 89(2): 201-219

Krumholz J, Jadot C, Barber T (2007) Reef Safe Fertilizer Disc Technology. Estuarine Research Foundation Meeting Presentation

Kukel CM, Hallberg RW, Oppenheimer M (2006) Coral reefs reduce tsumnami impact in model simulations. Geiophysical Research Letters 33:23

Levin N, Kidron GJ, \& BEN $\square$ DOR EYAL (2006). The spatial and temporal variability of sand erosion across a stabilizing coastal dune field. Sedimentology 53(4): 697-715

Lewis III RR (2000) Ecologically based goal setting in mangrove forest and tidal marsh restoration. Ecological Engineering, 15(3): 191-198

Lewis III RR (2005) Ecological engineering for successful management and restoration of mangrove forests. Ecological Engineering, 24(4): 403-418 
Lewis III RR (2009) Methods and criteria for successful mangrove forest restoration in GME Perillo, E Wolanski, DR Cahoon, and MM Brinson (eds.) Coastal Wetlands: An Integrated Ecosystem Approach.. Elsevier Press 28: 787-800

Lovelock CE, Feller IC, Ellis J, Schwarz AM, Hancock N, Nichols P, Sorrell B (2007) Mangrove growth in New Zealand estuaries: the role of nutrient enrichment at sites with contrasting rates of sedimentation. Oecologia, 153(3): 633-641

Macintosh DJ, Ashton EC, Havanon S (2002) Mangrove rehabilitation and intertidal biodiversity: a study in the Ranong mangrove ecosystem, Thailand. Estuarine, Coastal and Shelf Science 55.3: 331-345

Macintyre IG, Toscano MA (2004) The Pleistocene Limestone Foundation Below Twin Cays, Belize, Central, America. Smithsonian Institution, National Museum of Natural History

Mazda Y, Magi M, Kogo M, Hong PN (1997) Mangroves as a coastal protection from waves in the Tong King delta, Vietnam. Mangroves and Salt marshes, 1(2): 127-135

McKee KL (2011) Biophysical controls on accretion and elevation change in Caribbean mangrove ecosystems. Estuarine, Coastal and Shelf Science 1(4):475-483

McKee KL, Cahoon DR, \& Feller IC (2007) Caribbean mangroves adjust to rising sea level through biotic controls on change in soil elevation. Global Ecology and Biogeography 16(5):545-556

McKee KL, Faulkner PL (2000) Restoration of biogeochemical function in mangrove forests. Restoration Ecology 8(3): 247-259.

Moreno-Casasola P (1986) Sand movement as a factor in the distribution of plant communities in a coastal dune system. Plant Ecology 65: 67-76

Mumby PJ, Edwards AJ, Arias-Gonzalez JE, Lindeman KC, Blackwell PG, Gall A, Gorczynska MI, Harborne AR, Pescod CL, Renken H, Wabnitz CC, Llewellyn G (2004) Mangroves enhance the biomass of coral reef fish communities in the Caribbean. Nature 427:533-536

Primavera JH, Esteban JMA (2008) A review of mangrove rehabilitation in the Philippines: successes, failures and future prospects. Wetlands Ecology and Management, 16(5):345-358

Saenger P, Siddiqi NA (1993) Land from the sea: the mangrove afforestation program of Bangladesh. Ocean \& Coastal Management, 20(1):23-39

Salmo III, SG, Lovelock C, Duke NC (2013) Vegetation and soil characteristics as indicators of restoration trajectories in restored mangroves. Hydrobiologia, 720(1):118

Samson MS, Rollon RN (2008) Growth performance of planted mangroves in the Philippines: revisiting forest management strategies. AMBIO: A Journal of the Human Environment, 37(4): 234-240

Schmider E, Ziegler M, Danay E, Beyer L, Bühner M (2010). Is it really robust? Reinvestigating the robustness of ANOVA against violations of the normal distribution assumption. Methodology: European Journal of Research Methods for the Behavioral and Social Sciences 6(4): 147.

Sheppard C, Dixon DJ, Gourlay M, Sheppard A, Payet R (2005) Coral mortality increases wave energy reaching shores protected by reef flats: examples from the Seychelles. Estuarine, Coastal and Shelf Science 64(2):223-234 
Spenceley, AP (1982) Sedimentation patterns in a mangal on Magenetic Island near Townsville, North Queensland, Australia. Singapore Journal of Tropical Geography 3:100-107

Stevenson NJ (1997) Disused shrimp ponds: Options for redevelopment of mangroves. Coastal Management 25:425-435

Stevenson NJ, Lewis RR, Burbridge PR (1999) Disused Shrimp Ponds and Mangrove Rehabilitation. In: Streever W (ed) An International Perspective on Wetland Rehabilitation. Springer Netherlands : 277-297

Thampanya U, Vermaat JE, Sinsakul S, Panapitukkul N (2006) Coastal erosion and mangrove progradation of Southern Thailand. Estuarine, Coastal and Shelf Science 68:75-85

Valiela I, Bowen JL, York JK (2001) Mangrove Forests: One of the World's Threatened Major Tropical Environments. BioScience 51:807-815

Victor S, Neth L, Golbuu Y, Wolanski E, Richmond RH (2006) Sedimentation in mangroves and coral reefs in a wet tropical island, Pohnpei, Micronesia. Estuarine, Coastal and Shelf Science 66:409-416

Walters BB (2000) Local mangrove planting in the Philippines: are fisherfolk and fishpond owners effective restorationists? Restoration Ecology 8(3): 237-246

Walters BB, Rönnbäck P, Kovacs JM, Crona B, Hussain SA, Badola R, ... DahdouhGuebas $F$ (2008) Ethnobiology, socio-economics and management of mangrove forests: a review. Aquatic Botany, 89(2): 220-236

Williams N (2005) Tsunami insight to mangrove value. Current Biology 15:R73

Winterwerp JC, Borst WG, De Vries MB (2005) Pilot study on the erosion and rehabilitation of a mangrove mud coast. Journal of Coastal Research, 223-230

Wolanski E, Ridd P (1986) Tidal mixing and trapping in mangrove swamps. Estuarine, Coastal and Shelf Science 23:759-771

Woodruffe CD (2002) Coasts: form, process and evolution. Cambridge University Press, Cambridge, England mangrove swamps. Estuarine, Coastal and Shelf Science 23:759-771

Ye Y, Chen YP, Chen GC (2013) Litter production and litter elemental composition in two rehabilitated Kandelia obovata mangrove forests in Jiulongjiang Estuary, China. Marine environmental research, 83: 63-72 